Article

\title{
HTC of Wet Residues of the Brewing Process: Comprehensive Characterization of Produced Beer, Spent Grain and Valorized Residues
}

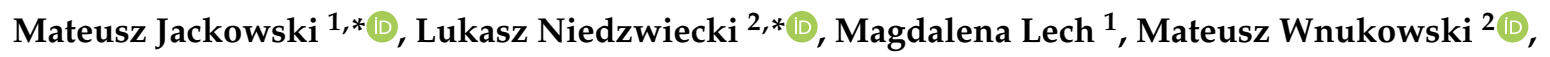 \\ Amit Arora ${ }^{3}$, Monika Tkaczuk-Serafin ${ }^{2}$, Marcin Baranowski ${ }^{2}$, Krystian Krochmalny ${ }^{2}$, \\ Vivek K. Veetil ${ }^{2}$, Przemysław Seruga ${ }^{4}{ }^{\infty}$, Anna Trusek ${ }^{1}$ and Halina Pawlak-Kruczek ${ }^{2}$ \\ 1 Department of Micro, Nano and Bioprocess Engineering, Faculty of Chemistry, Wroclaw University of \\ Science and Technology, Norwida 4/6, 50-373 Wrocław, Poland; magdalena.lech@pwr.edu.pl (M.L.); \\ anna.trusek@pwr.edu.pl (A.T.) \\ 2 Department of Mechanics, Machines, Devices and Energy Processes, Faculty of Mechanical and Power \\ Engineering, Wroclaw University of Science and Technology, Wybrzeże Wyspiańskiego 27, \\ 50-373 Wrocław, Poland; mateusz.wnukowski@pwr.edu.pl (M.W.); monika.tkaczuk@pwr.edu.pl (M.T.-S.); \\ marcin.baranowski@pwr.edu.pl (M.B.); krystian.krochmalny@pwr.edu.pl (K.K.); \\ 904694@student.pwr.edu.pl (V.K.V.); halina.pawlak-kruczek@pwr.edu.pl (H.P.-K.) \\ 3 Department of Chemical Engineering, Shaheed Bhagat Singh State Technical Campus, Ferozepur, \\ Punjab 152004, India; aroraamitlse@yahoo.com \\ 4 Department of Bioprocess Engineering, Wroclaw University of Economics, Komandorska 118/120, \\ 53-345 Wrocław, Poland; przemyslaw.seruga@ue.wroc.pl \\ * Correspondence: mateusz.jackowski@pwr.edu.pl (M.J.); lukasz.niedzwiecki@pwr.edu.pl (L.N.)
}

Received: 30 March 2020; Accepted: 16 April 2020; Published: 20 April 2020

Abstract: Steady consumption of beer results in a steady output of residues, i.e., brewer's spent grain (BSG). Its valorization, using hydrothermal carbonization (HTC) seems sensible. However, a significant knowledge gap regarding the variability of this residue and its influence on the valorization process and its potential use in biorefineries exists. This study attempted to fill this gap by characterization of BSG in conjunction with the main product (beer), taking into accounts details of the brewing process. Moreover, different methods to assess the performance of HTC were investigated. Overall, the differences in terms of the fuel properties of both types of spent grain were much less stark, in comparison to the differences between the respective beers. The use of HTC as a pretreatment of BSG for subsequent use as a biorefinery feedstock can be considered beneficial. HTC was helpful in uniformization and improvement of the fuel properties. A significant decrease in the oxygen content and $\mathrm{O} / \mathrm{C}$ ratio and improved grindability was achieved. The Weber method proved to be feasible for HTC productivity assessment for commercial installations, giving satisfactory results for most of the cases, contrary to traditional ash tracer method, which resulted in significant overestimations of the mass yield.

Keywords: hydrothermal carbonization; hydrochars; beer; brewers spent grain; pyrolysis

\section{Introduction}

Beer is a beverage which can be characterized by a reasonably steady consumption in OECD (Organization for Economic Co-operation and Development) countries [1]. As the OECD consists of developed countries, where a reasonably steady financial situation of citizens can be reasonably assumed, it seems reasonable to assume a steady output of residues, such as spent grain, as a consequence of this consumption. Currently, this residue is mainly used as fodder in agriculture [2]. 
However, for craft breweries located in big cities, disposal becomes more problematic [3]. There are also attempts to enrich food products with spent grains. Thus far, there have been trials with sausages [4] and bread [5]. However, consumers reported that such products represent a fiber aftertaste [6]. However, this is limited only to the relatively close vicinity of a brewery, due to relatively high moisture content, that could range between $70 \%$ up to $78 \% 70 \%$ [7-9]. Biological activity of these residues makes long term storage difficult. The literature reports ongoing work on various new ways of using BSG, including extraction of polyphenols [10,11], other anti-oxidants [12,13], functional cardioprotective lipids for pharmaceutic use [14], proteins [15], fodder for edible insects [16], material for disposable trays [17], natural rubber modifier [18], as well as feedstock for production of pigments [19] and biochar, for subsequent use as soil amendment [20] or sustainable material for electrodes [21].

The potential use of this residue as a fuel has been suggested by several authors so far [7-9,22,23]. The relatively high initial moisture content of spent grain makes hydrothermal valorization techniques the most sensible choice [8,9]. Hydrothermal carbonization (HTC), also known as wet torrefaction, is a valorization process suitable for a range of low-quality solid biomass, especially with high initial moisture content $[24,25]$. Process temperature, reported in the literature, usually ranges between $180^{\circ} \mathrm{C}$ and $260^{\circ} \mathrm{C}$ [25-30]. As the process takes place in subcritical water, pressure has to be higher than saturation pressure of water for specific temperature [25-30]. In these conditions water behaves as a non-polar solvent and its ionic constant increases significantly [31]. A multitude of concurring reactions takes place during HTC and a multitude of different products is obtained as a result $[25,27]$. Firstly, the biomass is degraded by hydrolysis to a vast number of different monomers and oligomers [25] as well as some intermediates [24,25]. In general, the rate of hydrolysis is diffusion-controlled [32]. Therefore, the limitation of transport phenomena is an important factor, especially taking into the account the complexity of fibrous structure different for various types of biomass [32]. Therefore, hydrolysis can be enhanced by the overall increase in the process temperature [33-35]. Hydrolysis is followed by dehydration and decarboxylation $[24,25,36]$. Dehydration decreases the number of $\mathrm{OH}$ groups [25]. Colloidal structures are destroyed, thus decreasing the number of hydrophilic groups and promoting the formation of gases (mainly $\mathrm{CO}_{2}$ ) [27]. $\mathrm{CO}$ can also be detected, along with $\mathrm{CH}_{4}$, and $\mathrm{H}_{2}$ for the case of catalytic processes [33,34]. The decrease in the amount of hydroxyl groups is the cause of decreased $\mathrm{O} / \mathrm{C}$ ratio of solid products. The amount of carboxyl $(\mathrm{COOH})$ and carbonyl $(\mathrm{C}=\mathrm{O})$ groups is decreased, which attributes to the decreased $\mathrm{O} / \mathrm{C}$ ratio of the solid product [25]. This is followed by polymerization and aromatization [24,25]. A decrease in the number of $\mathrm{OH}$ groups is crucial in making hydrochars hydrophobic [37] and enhancing dewatering by mechanical means [25,38]. Moreover, grindability of the processed biomass can be significantly enhanced [39]. Therefore, HTC can be considered as a prospective valorization process for low quality biomass, especially when wet biomass is concerned as a potential feedstock for biorefineries [40-45] or as a component of high quality solid biofertilizers [44,46,47].

Performance of the HTC process is typically determined directly, by means of mass yield, energy yield and energy densification ratio $[24,27,41-43,48]$. Recently some studies attempted using an indirect method for this purpose [8], originally developed for production of biochar [49]. The use of an indirect method is tempting, especially that it does not require to check the mass of the whole batch after HTC, which could be especially cumbersome and impractical for future industrial-scale installations. However, more research is needed to confirm the suitability of this method for assessment of the productivity of the HTC process in general, as well as specifically for its use for the spent grain.

Drying of BSG was investigated by Arranz et al. [50]. The study showed that significant drying time, exceeding $100 \mathrm{~min}$ is required to remove $80 \%$ of the original moisture [50]. Obtained effective diffusities were significantly lower than those reported for olive pomace, making BSG a much more challenging material in terms of its drying [50]. Dudek et al. [51] investigated use of BSG as a feedstock for anaerobic digestion (AD), as well as using BSG torrefaction as a mean to produce an AD additive [51]. The information available in the published literature on hydrothermal carbonization of brewer's spent grain (BSG) is not extensive. Jackowski et al. performed a gas chromatography-mass 
spectrometry (GC-MS) analysis of the liquid by-product of the HTC of spent grain and suggested its utilization in the anaerobic digestion process [8]. Arauzo et al. studied the effect of hydrothermal carbonization of the spent grain from a big scale brewery and noticed an improvement in fuel properties, such as increased higher heating value (HHV) and decreased ash content (for high water: biomass ratios) [9]. The study also concluded that low temperatures of the HTC process are suitable, due to the high content of hemicellulose in the feedstock [9]. Poerschmann et al. [52] observed that phenols, benzenediols, and fatty acids are released from bound lipids during the HTC process. Moreover, the study reported the suitability of hydrochars from BSG for soil-improvement applications [52]. Olszewski et al. [53] performed Py-GC-MS analysis BSG and corresponding hydrochars. A significant amount of $\mathrm{N}$-compounds was detected at low pyrolysis temperature for spent grains, owing to weakly bonded proteins [53]. Whereas, hydrochars were characterized by fewer $\mathrm{N}$-compounds released during pyrolysis, in comparison to BSG [53]. This was attributed to the Maillard reaction occurring during hydrothermal carbonization, leading to more stable N-heterocycles structures [53]. Moreover, comparison between single-step pyrolysis process and two-step process, consisting of HTC and pyrolysis, has been made by Olszewski et al. for BSG [54]. The study reported removal efficiency of inorganics for HTC temperatures between $180^{\circ} \mathrm{C}$ and $260{ }^{\circ} \mathrm{C}$, ranging from almost $60 \%$ to more than $95 \%$ for K, approx. $45 \%$ to approx. $55 \%$ for $\mathrm{P}$, and approx. $35 \%$ up to approx. $75 \%$ for $\mathrm{Na}$ [54]. Furthermore, the study reported increased BET surface for pyrochars from two-step process, with HTC performed at $180{ }^{\circ} \mathrm{C}$ and $220^{\circ} \mathrm{C}$ and pyrolysis at $600^{\circ} \mathrm{C}$, in comparison to single step pyrolysis at the same temperature [54].

Currently published studies are focused on the carbonization process of the spent grain. However, none of the published works gives an indication, if grain used for brewing, as well as the parameters of the brewing process, have any influence on the HTC process as well as on the characteristics of the spent grain and corresponding hydrochars. The aim of this research is to determine if the brewing process has any effect on the fuel parameters of spent grain and hydrochars and their respective suitability as feedstock for biorefineries. Moreover, the study also aims at a comparison between the use of direct and two different indirect methods for assessment of the performance of the HTC process in the valorisation of spent grain for energy purposes.

\section{Materials and Methods}

\subsection{Characterisation of the Main Product-Beer}

The samples of the main product, i.e., beer made in were analysed using various analytical techniques. The alcohol content was measured using Shimadzu 2010 gas chromatograph equipped with an FID detector. Injector temperature was set to $140{ }^{\circ} \mathrm{C}$, detector to $200^{\circ} \mathrm{C}$. The split ratio was set at 30:1. Analysis was performed on ZB-WAXplus column ( $\mathrm{L}=30 \mathrm{~m} \times \mathrm{I}$.D. $=0.25 \mathrm{~mm} \times \mathrm{df}=0.25 \mathrm{~m}$ ). Temperature program was set from $35^{\circ} \mathrm{C}$ for $5 \mathrm{~min}$, then raised to $85^{\circ} \mathrm{C}$ (at $10^{\circ} \mathrm{C} / \mathrm{min}$ ) and in the next step raised up to $200^{\circ} \mathrm{C}$ (at $25^{\circ} \mathrm{C} / \mathrm{min}$ ). The procedure ended with a hold period at $200^{\circ} \mathrm{C}$ for $1 \mathrm{~min}$. Beer extract was measured using Funke Gerber Fermento Flash beer analyser. Results are given in Brix degrees, $1^{\circ} \mathrm{Bx}$ is equal to $1 \mathrm{~g}$ of sucrose in $100 \mathrm{~g}$ of solution.

An Agilent 7820 gas chromatograph coupled to an Agilent 5977B MSD Electron ionization mass spectrometer was used to determine the content of organic compounds, other than ethanol and water, present in beers. Samples of $0.5 \mu \mathrm{l}$ were introduced into the GC injector $\left(200{ }^{\circ} \mathrm{C}\right.$; split $\left.=2\right)$; helium was used as a mobile phase $(2.0 \mathrm{~mL} / \mathrm{min})$. The gas chromatograph was equipped with Stabilwax-DA column $\left(30 \mathrm{~m} \times 0.32 \mathrm{~mm} \times 0.25 \mu \mathrm{m}\right.$; Restek). The temperature program was set to holding at $50{ }^{\circ} \mathrm{C}$ for $5 \mathrm{~min}$ at first, following with subsequent temperature increase, with heating rate of $10^{\circ} \mathrm{C} / \mathrm{min}$, up to $200^{\circ} \mathrm{C}$ and holding period of $5 \mathrm{~min}$. NIST-14 MS library was used for automatic identification of detected compounds by comparing mass spectra with the library's content. Only compounds with minimum match factor of $90 \%$, in comparison to NIST library, were taken into account. The MS scanning range was $\mathrm{m} / \mathrm{z} 10-450$ with the frequency of $1.7 \mathrm{scan} / \mathrm{sec}$. The gain factor and EM Volts 
were 3.0 and 1708 , respectively. The MS source temperature was $230^{\circ} \mathrm{C}$, whereas the quadrupole temperature was $150^{\circ} \mathrm{C}$. Additionally to barley and wheat-based beers, GC-MS analysis was performed for a commercially available beer, namely Primátor Weizen, brewed in the Czech Republic.

\subsection{Characterisation of By-Product-Spent Grain before and after Carbonisation}

Both raw and HTC treated spent grain were a subject of thermogravimetric analysis and differential thermogravimetry (TGA/DTG) analysis. The TGA/DT Pyris Diamond, manufactured by Perkin Elmer, was used. Analysis was performed according to a two-step program. Firstly, the sample was heated in up to $105{ }^{\circ} \mathrm{C}$ (heating rate of $10^{\circ} \mathrm{C} / \mathrm{min}$ ), followed by a hold period of $20 \mathrm{~min}$. During the second step, the sample was heated up to $900{ }^{\circ} \mathrm{C}$ with a heating rate of $10^{\circ} \mathrm{C} / \mathrm{min}$. The nitrogen of $99.999 \%$ purity was used as inert gas. Fine particles, of particle size smaller than $200 \mu \mathrm{m}$, were used.

Ash content was determined using a gravimetric procedure, as described in EN 18122 [55], for combustion in a furnace at the temperature of $550{ }^{\circ} \mathrm{C}$, using porcelain dishes. Volatile content was determined using a gravimetric procedure, as described in EN 15148 [56]. Samples in closed corundum crucibles were kept in the furnace, heated up to $900{ }^{\circ} \mathrm{C}$, for the time of $7 \mathrm{~min}$. The Perkin Elmer 2400 analyzer was used for the ultimate analysis, which was performed in compliance with the procedure set in the standard EN ISO 16948 [57]. Friedl formula [58] was used to estimate the HHV of both digestates and corresponding hydrochars:

$$
\mathrm{HHV}=3.55 \cdot \mathrm{C}^{2}-232 \cdot \mathrm{C}-2230 \cdot \mathrm{H}+51.2 \cdot \mathrm{C} \cdot \mathrm{H}+131 \cdot \mathrm{N}+20600, \mathrm{~kJ} / \mathrm{kg}
$$

where $\mathrm{C}, \mathrm{H}, \mathrm{N}$ represent carbon, hydrogen and nitrogen, respectively, in dry biomass (i.e., values of $\mathrm{C}, \mathrm{H}$ and $\mathrm{N}$ are substituted, without $\%$ sign, using values from the ultimate analysis). The result of the calculation gives $\mathrm{HHV}$ with $\mathrm{kJ} / \mathrm{kg}$ unit. Coefficients have been rounded to three significant digits. This formula was chosen, due to the fact among different types of biomass cereals were also included, which is a material relatively close, from the morphology point of view to spent grain. Friedl et al. reported a standard error of calibration of $337 \mathrm{~kJ} / \mathrm{kg}$ and an $\mathrm{R}^{2}$ coefficient of 0.943 achieved during validation of the formula (1) against the experimental results [58].

Grindability of the dried feedstocks and respective hydrochars was determined by grinding in Retsch SM100 knife mill. A screen with an aperture of $200 \mu \mathrm{m}$ was used in the mill. Batches of approximately $200 \mathrm{~mL}$ of dried material were fed into the mill every 5 min until all dry material of particular HTC test was fed into the mill. For the case of both feedstocks, $400 \mathrm{~g}$ of dried material was used for grinding. Each of the materials, after comminutions, was a subject of sieving. A set of sieves with apertures of $1000,800,630,500,400,300,200,100$ and $50 \mu \mathrm{m}$ was used in a sieve shaker to perform the particle size analysis. Sieving was performed for $30 \mathrm{~min}$ for each of the tests. Balance with the measurement uncertainty of $0.1 \mathrm{~g}$ was used for each test to check the total mass of particles, left on each sieve and the bottom pan.

\subsection{Beer Brewing-Experimental Procedure and Description of the Experimental Setup}

Both beers were produced in a pilot-scale brewing installation, similar to a typical, small restaurant located, craft brewery, located at the Wrocław University of Science and Technology. This installation allows producing approximately $1 \mathrm{hl}$ of beer per batch, with full control over each individual unit operation of the process (Figure 1). The installation uses electricity for simplicity and convenience. However, the process heat and cold necessary for some unit operations of the brewing process (Figure 1) can potentially be delivered by other means, from other sources. 


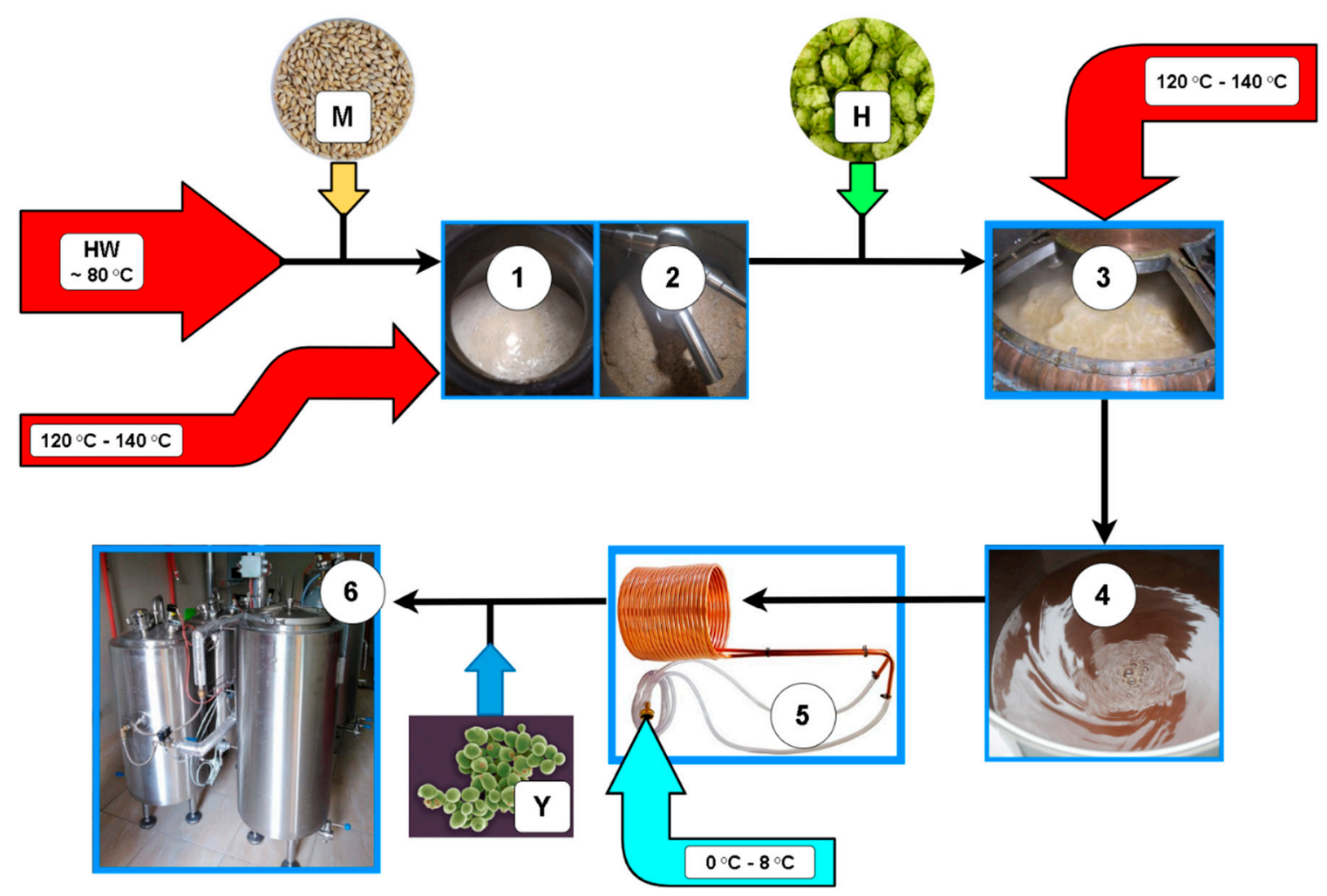

Figure 1. Pilot-scale installation diagram, with special emphasis on unit operations with heat/cold demand. Heat supply marked with red arrows, cold supply marked with a cyan arrow (1-mashing; 2-lautering; 3-boiling; 4-wort separation in a whirlpool; 5-wort cooling; 6-fermentation; M-malt; H-hops; Y - yeasts).

Beer recipes were prepared to represent two styles, distinctly different from one another and in the same time most commonly available on the market, i.e., barley beer and wheat beer. Barley-based beer was produced using, previously ground, $28 \mathrm{~kg}$ of pilsner malt with $70 \mathrm{~L}$ of water. Mashing regime was $48^{\circ} \mathrm{C}$ for $15 \mathrm{~min}, 63^{\circ} \mathrm{C}$ for $20 \mathrm{~min}$ and $73^{\circ} \mathrm{C}$ for $23 \mathrm{~min}$. Mashing was ended with temperature rise to $78^{\circ} \mathrm{C}$ in order to kill remained enzymes. After separating sugar solution from spent grains (152 g of juniper was used as a filtration aid), $33 \mathrm{~L}$ of water were used for sparging remaining grains. The wort was boiled for $60 \mathrm{~min}$. At the beginning of boiling $150 \mathrm{~g}$ of Marynka hop was added. The next dose of hops-180 g of Marynka was added $15 \mathrm{~min}$ before the end of boiling. Finally, the wort was cooled down to $10^{\circ} \mathrm{C}$, and $45 \mathrm{~g}$ of dried lager yeasts were added. Wort gravity was 17.78 Brix. Fermentation lasted for 2 weeks at $12{ }^{\circ} \mathrm{C}$. Finally, yeasts were removed, and beer was conditioned in $5^{\circ} \mathrm{C}$ for another 2 weeks.

Wheat-based beer was produced, using $4.2 \mathrm{~kg}$ of pilsner malt, $4.2 \mathrm{~kg}$ of wheat malt and $0.4 \mathrm{~kg}$ of caramel malt. Before mashing, grains were ground and mixed with $40 \mathrm{~L}$ of water. Mashing regime started at $44^{\circ} \mathrm{C}$ for $20 \mathrm{~min}$. Then the temperature was raised to $63^{\circ} \mathrm{C}$, and a hold period of $45 \mathrm{~min}$ was applied. Finally, the temperature step was $73^{\circ} \mathrm{C}$ for $20 \mathrm{~min}$. Mashing was ended with a temperature rise to $78^{\circ} \mathrm{C}$. After separating sugar solution from spent grains, approximately $12 \mathrm{~L}$ of water were used for sparging remained grains. Achieved wort was boiled for $60 \mathrm{~min}$. At the beginning of boiling $30 \mathrm{~g}$ of Hallertau hop was added, next dose of hops-30 $\mathrm{g}$ of Marynka was added $15 \mathrm{~min}$ before the end of boiling. Finally, the wort was cooled down to $20^{\circ} \mathrm{C}$, and $22 \mathrm{~g}$ of dried WB-06 yeast was added. Wort gravity was 8.2 Brix. Fermentation lasted for 1 week at $23^{\circ} \mathrm{C}$. Finally, yeasts were removed, and beer was conditioned in $7^{\circ} \mathrm{C}$ for another 1 week. 


\subsection{Hydrothermal Carbonisation-Experimental Rig and Characterisation of the Process}

HTC was performed, using an autoclave (Figure 2) with a working volume of $4000 \mathrm{ml}$, able to withstand a temperature of $200{ }^{\circ} \mathrm{C}$ and pressure of 150 bar. The autoclave is equipped with a stirrer (Figure 2). However, it was not utilized during the experiments. For each experiment, approximately $400 \mathrm{~g}$ of dried spent grain was put into empty autoclave vessel and subsequently filled with water, up to the marking point, above which a freeboard of $500 \mathrm{ml}$ remained. After sealing of the autoclave, the autoclave vessel was heated up by a heating mantle, with band heaters. K type thermocouple, connected to a PLC controller, was used in order to measure and control the process temperature. Products were drained, after cooling down of the installation, using a clean colander and a clean fabric filter. Drained material was subsequently dried. Process parameters of all performed hydrothermal carbonization experiments are given in an experimental matrix, presented in Table 1.

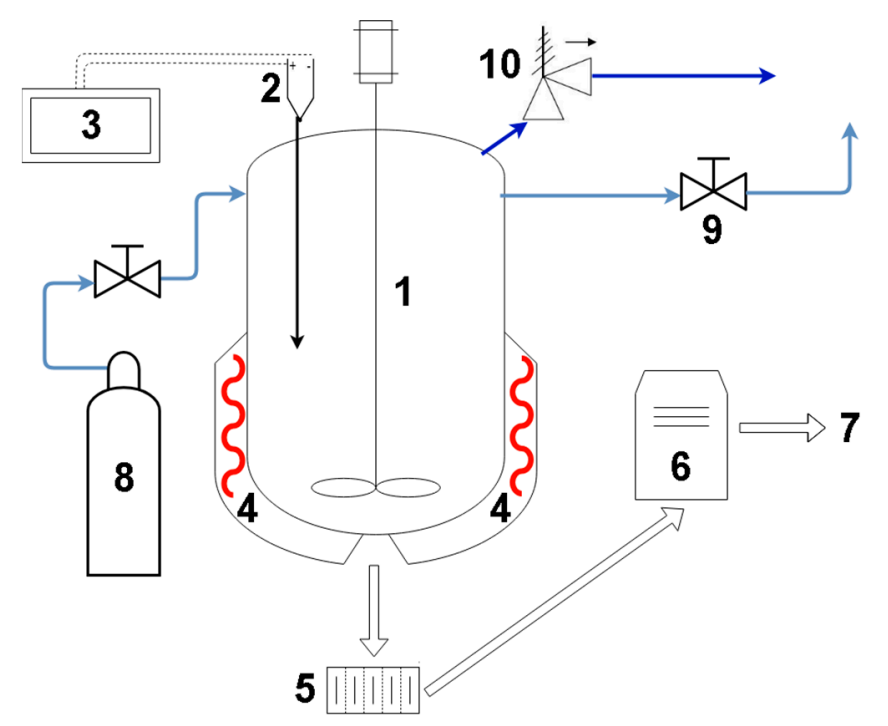

Figure 2. Diagram of the experimental hydrothermal carbonization (HTC) rig (1-Autoclave; 2-type K thermocouple; 3-PLC controller; 4-heating mantle, with band heaters; 5-draining; 6-dryer; 7-analysis of dry sample; 8-nitrogen for purging; 9-purging valve; 10-pressure relief valve).

Table 1. Experimental matrix for the suite of hydrothermal carbonization experiments.

\begin{tabular}{cccc}
\hline Sample & $\begin{array}{c}\text { HTC Temperature } \\
{ }^{\circ} \mathbf{C}\end{array}$ & $\begin{array}{c}\text { Residence Time } \\
\text { min }\end{array}$ & $\begin{array}{c}\text { Average Heating Rate }{ }^{\mathbf{1}} \\
{ }^{\circ} \mathbf{C} / \mathbf{m i n}\end{array}$ \\
\hline Barley-raw spent grain & - & - & - \\
Barley, $180{ }^{\circ} \mathrm{C}, 10 \mathrm{~min}$ & 180 & 10 & 3.7 \\
Barley, $200{ }^{\circ} \mathrm{C}, 10 \mathrm{~min}$ & 200 & 10 & 2.9 \\
Barley, $200{ }^{\circ} \mathrm{C}, 60 \mathrm{~min}$ & 200 & 60 & 3.1 \\
\hline Wheat-raw spent grain & - & - & - \\
Wheat, $200^{\circ} \mathrm{C}, 10 \mathrm{~min}$ & 200 & 10 & 2.7 \\
Wheat, $200^{\circ} \mathrm{C}, 60 \mathrm{~min}$ & 200 & 60 & 2.1 \\
Wheat, $200{ }^{\circ} \mathrm{C}, 120 \mathrm{~min}$ & 200 & 120 & 2.4 \\
\hline
\end{tabular}

${ }^{1}$ Average heating rate, during respective HTC experiments.

Process parameters given in Table 1 were selected, based on previous works on HTC of spent grain $[8,9]$. It was considered by the authors, that for commercial-scale processes temperature would be minimized, as HTC process is performed under relatively high pressures, which is determined by the saturation temperature of the water, which keeps the majority of water liquid. According to Arauzo et al., $180{ }^{\circ} \mathrm{C}$ is enough to degrade polycarbohydrates [9]. Therefore, the study focused on the lower range of temperatures, typical for HTC process [27]. The residence time was deemed to 
be potentially important for commercial-scale installations, as it determines the productivity for the installation of a given size. This seems to be in good agreement with reported parameters used by commercial HTC reactors for HTC of sewage sludge [59].

Mass yield $\left(Y_{m}\right)$ and energy yield $\left(Y_{e}\right)$ were used for assessment of performance and productivity, as typically used indicators [49,60-62]. Weber method was used, as one of the indirect methods of assessment of mass yield [49]:

$$
Y_{m \text { Weber }}=\frac{1-V M_{\text {feedstock }}}{1-V M_{\text {product }}}
$$

where: $Y m$-mass yield (further part of the subscript indicating a method); $V M$-respective volatile matter content of feedstock and product, $\%$ dry

Moreover, the mass yield was also assessed, using well-established ash tracer method, used for indirect assessment of mass losses, during various thermal conversion processes [63]:

$$
Y_{m \text { ash tracer }}=\frac{A_{\text {feedstock }}}{A_{\text {product }}}
$$

where: $Y m$-mass yield (further part of the subscript indicating a method); $A$-respective ash content of feedstock and product, dry basis, $\%_{\mathrm{db}}$

A well-established formula was used for calculation of the energy yield [61,64,65]:

$$
Y_{e}=Y_{m} \cdot \frac{H H V_{\text {product }}}{H H V_{\text {feedstock }}}
$$

where: $Y_{e}$-energy yield; $H H V$-respective higher heating value of feedstock and product, $\mathrm{MJ} / \mathrm{kg}$

Ash yield was used, as suggested by Wnukowski et al. [39] and Mościcki et al. [27], as a typical indicator of the inorganic's behaviour during HTC process:

$$
Y_{a}=Y_{m} \cdot \frac{A_{\text {product }}}{A_{\text {feedstock }}}
$$

where: $Y_{a}$-ash yield

\section{Results and Discussions}

Overall, it could be reasonably stated that the differences in the feedstock and the brewing process resulted in two distinctly different beers. The barley-based beer had $7.6 \%$ alcohol by volume and the extract of 3.2 Brix, whereas the wheat-based beer had 3.8\% alcohol by volume and extract of 1.7 Brix. GC-MS results (Table 2) show that produced beers exhibited significant differences in terms of detected aroma compounds. It could be attributed to the various malt composition in both beers and mostly thanks to differences in yeasts used for production. Moreover, it should not be overlooked that higher and richer content of aroma compounds could be found in experimental beers, in comparison to the one produced with the industrial brewing process. This may be a result of the standardization of procedures used by industrial breweries. What is more, beers brewed in the same style may have significant differences in their aroma profile or even lack in some compounds in comparison to others [66]. Thus, it seems reasonable to also expect some differences between respective by-products.

Results of proximate analysis (Figure 3) showed that in terms of fuel properties, both types of spent grain were similar. As expected, hydrothermal carbonization resulted in a decrease of volatile matter content, for both feedstocks. This is in good qualitative agreement with literature results for many different types of biomass $[40,43,67,68]$. 
Table 2. Results of GC-MS analysis of main products (beers). Values of peaks excluding water and ethanol. All compounds with match factor $\geq 90 \%$, detected by NIST-14 MS library, presented and separated using "/". Order accordingly to respective match factors.

\begin{tabular}{|c|c|c|c|}
\hline Compound & $\begin{array}{l}\text { Barley-Based } \\
\text { Beer }\end{array}$ & $\begin{array}{l}\text { Wheat-Based } \\
\text { Beer }\end{array}$ & $\begin{array}{l}\text { Primátor } \\
\text { Weizen }\end{array}$ \\
\hline & a.u. ${ }^{1}$ & a.u. ${ }^{1}$ & a.u. ${ }^{1}$ \\
\hline 1-Butanol, 3-methyl- / 1-Pentanol & 781,362 & $3,160,527$ & n.d. ${ }^{2}$ \\
\hline 2-Propanone, 1-hydroxy & 245,906 & 202,954 & 274,030 \\
\hline Acetic acid / Ammonium acetate & $3,154,572$ & $2,101,582$ & 802,539 \\
\hline $\begin{array}{c}\text { 2,3-Butanediol / 2,3-Butanediol, }\left[\mathrm{R}-\left(\mathrm{R}^{*}, \mathrm{R}^{*}\right)\right]-/ \\
\text { 2,3-Butanediol, }\left[\mathrm{S}-\left(\mathrm{R}^{*}, \mathrm{R}^{*}\right)\right]^{3}\end{array}$ & $4,012,472$ & 643,145 & $3,721,274$ \\
\hline $\begin{array}{c}\left.\text { 2,3-Butanediol / 2,3-Butanediol, [R- }\left(\mathrm{R}^{*}, \mathrm{R}^{*}\right)\right] \text { - / } \\
\text { 2,3-Butanediol, }\left[\mathrm{S}-\left(\mathrm{R}^{*}, \mathrm{R}^{*}\right)\right]^{3}\end{array}$ & $2,008,409$ & 493,655 & $1,512,920$ \\
\hline $\begin{array}{l}\text { 2-Furanmethanol / 3-Furanmethanol / } \\
\text { Methylenecyclopropanecarboxylic acid }\end{array}$ & $2,432,529$ & 322,155 & $1,307,080$ \\
\hline Phenylethyl Alcohol / Hydrazine, (phenylmethyl)- & $2,763,552$ & $6,186,847$ & $3,200,241$ \\
\hline Maltol & $2,689,918$ & 591,574 & $4,307,609$ \\
\hline $\begin{array}{c}\text { (S)-(+)-2', } 3^{\prime} \text {-Dideoxyribonolactone / } \\
\text { 5-Hydroxymethyldihydrofuran-2-one }\end{array}$ & 650,481 & 92,640 & n.d. \\
\hline $\begin{array}{c}\text { 4H-Pyran-4-one, } \\
\text { 2,3-dihydro-3,5-dihydroxy-6-methyl- }\end{array}$ & 208,087 & n.d. & 92,069 \\
\hline Glycerin & $29,365,286$ & $31,641,608$ & $30,998,826$ \\
\hline $\begin{array}{l}\text { (S)-(+)-2', 3'-Dideoxyribonolactone / } \\
\text { 5-Hydroxymethyldihydrofuran-2-one }\end{array}$ & 40,841 & 85,481 & n.d. \\
\hline 5-Hydroxymethylfurfural & 470,982 & n.d. & n.d. \\
\hline 2(3H)-Furanone, dihydro-4-hydroxy- & 240,062 & n.d. & n.d. \\
\hline
\end{tabular}

${ }^{1}$ a.u.-arbitrary unit; ${ }^{2}$ n.d.-not detected; ${ }^{3}$ two peaks detected, belonging to butanediol or one of its isomers (order of the match factors of respective compounds exactly the same for both cases).

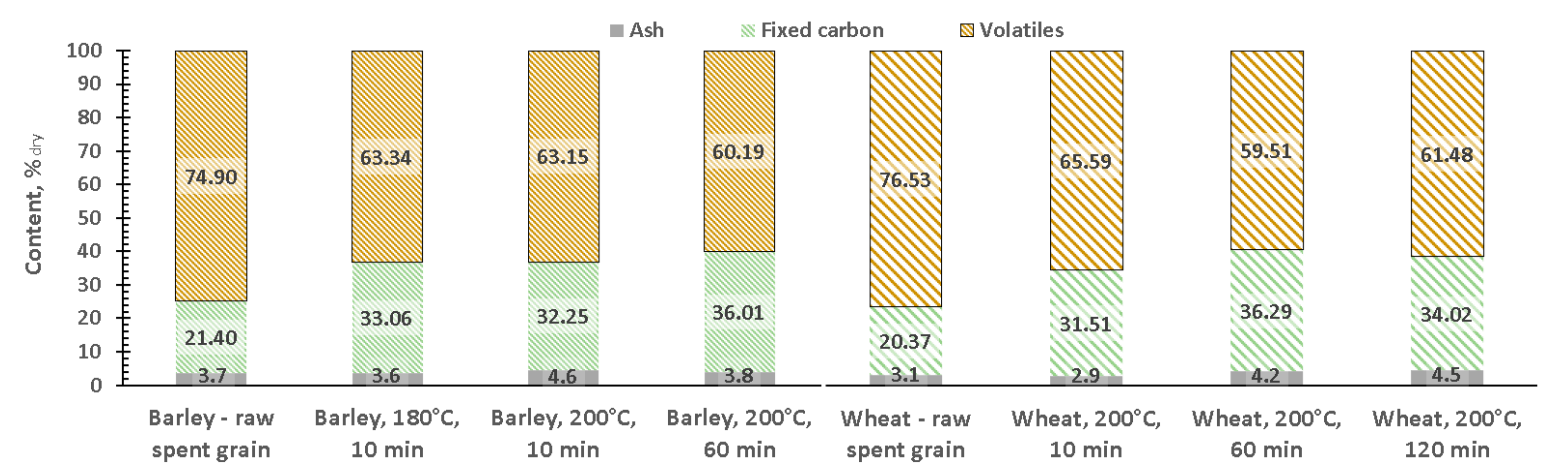

Figure 3. Results of the proximate analysis of all carbonized samples and dried feedstocks.

Increased higher heating values of hydrochars were obtained, in comparison to corresponding feedstocks (Figure 4). This is a direct consequence of the results of the ultimate analysis, as HHV was calculated for each sample, using Friedl formula (1). Nonetheless, the results obtained with this formula should be regarded as accurate for several reasons. Firstly, the standard error of calibration of $337 \mathrm{~kJ} / \mathrm{kg}$ and an $\mathrm{R}^{2}$ coefficient of 0.943 achieved during validation of the against the experimental results $[58,69]$. Secondly, cereals were used among the materials, used for the validation formula. As grains of various types of cereals are feedstock materials for malts, this could be considered as a material relatively close to the spent grain. Finally, the increase in HHV of material, after hydrothermal carbonization, is generally accepted trend, confirmed for various different types of feedstocks $[67,70]$.

As could be reasonably expected from HTC process, carbonization resulted in increased C content and decreased $\mathrm{O}$ content, which is rather typical for this process [47,71,72]. In general, significant decrease in the oxygen content and $\mathrm{O} / \mathrm{C}$ ratio (Figure 5) suggests that HTC could be a suitable pretreatment if the spent grain was meant to be used as a biorefinery feedstock, as available literature 
considers high oxygen content detrimental for the quality and stability of the pyrolysis oil, attributed to the oxygenated compounds [73-75].

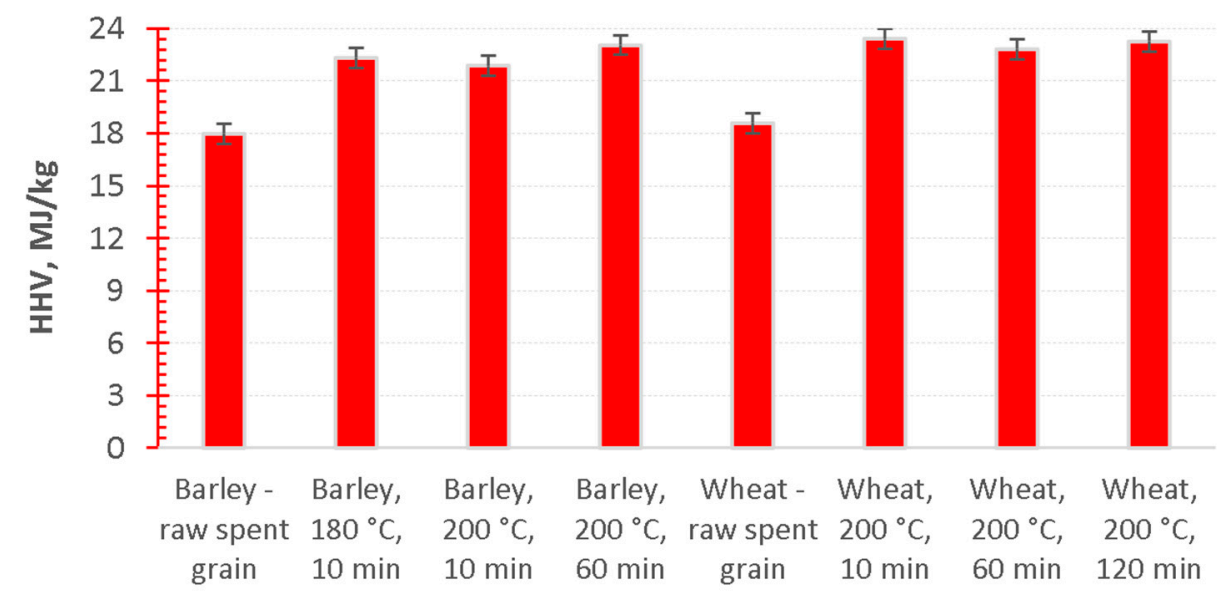

Figure 4. Higher heating value of feedstocks and respective hydrochars.

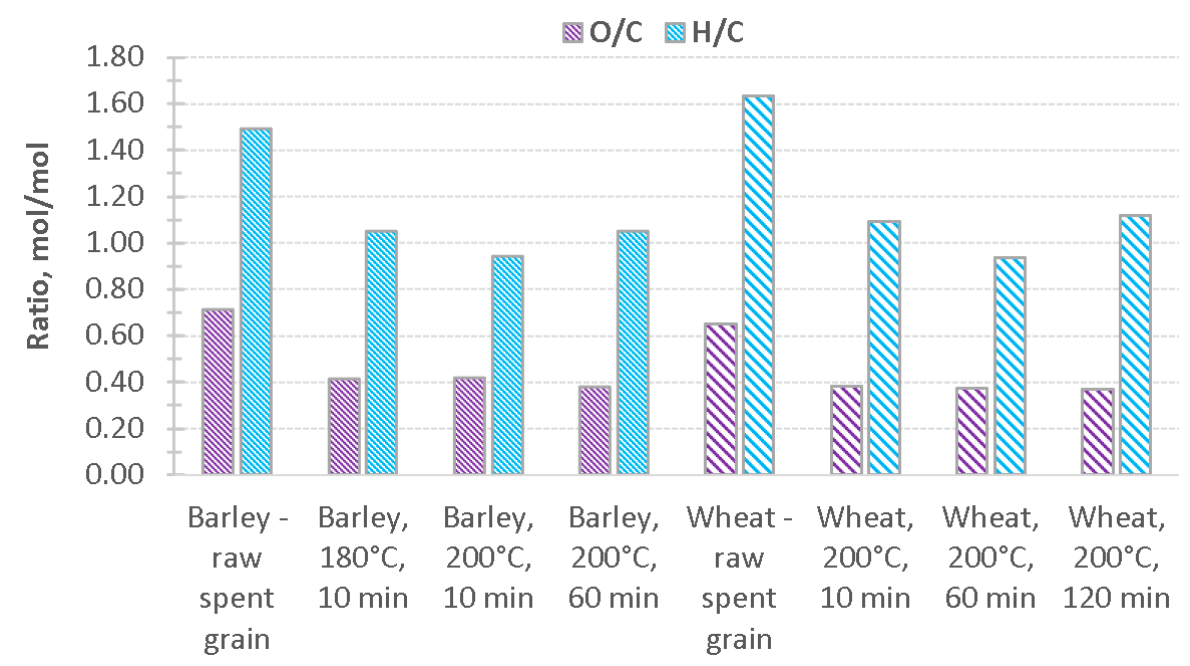

Figure 5. Molar ratios $(\mathrm{O} / \mathrm{C}$ and $\mathrm{H} / \mathrm{C})$ for feedstocks and respective hydrochars.

One difference between the two feedstocks that can be clearly observed is the nitrogen content (Figure 6), which was 3.96\% daf for barley and 6.86\% daf for wheat BSG. Relatively higher nitrogen content of wheat spent grain could be attributed to relatively higher protein content in wheat $[76,77]$.

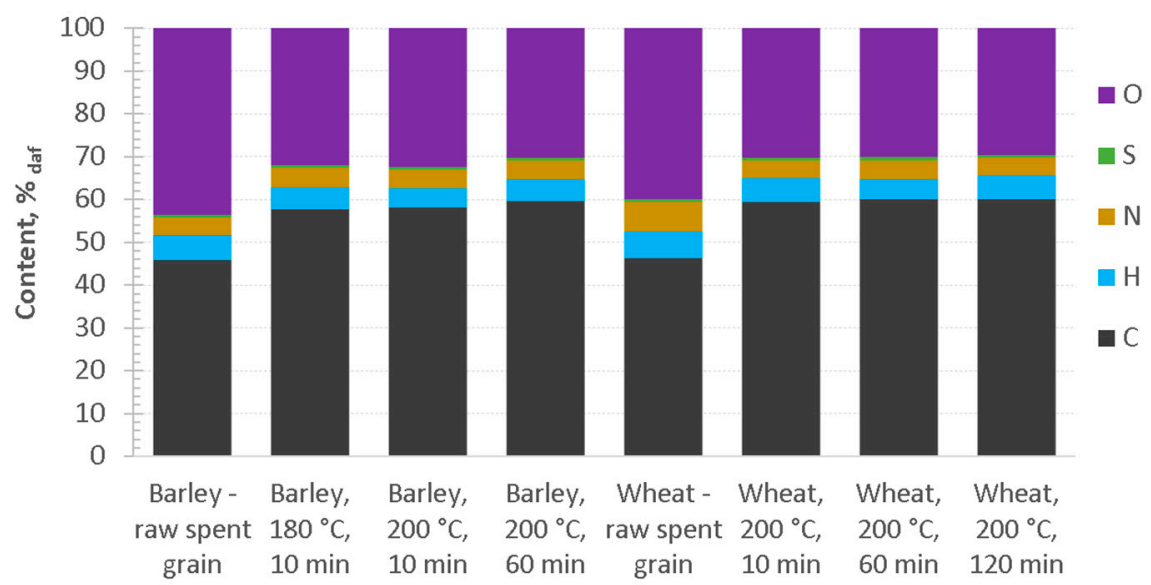

Figure 6. Ultimate analysis results for feedstocks and respective hydrochars. 
Nonetheless, it should not be overlooked that nitrogen content of hydrochars was fairly similar, for both types of feedstock. Therefore, it seems sensible to hypothesize that part of nitrogen was removed due to thermal degradation of proteins during the HTC process. This decrease of nitrogen content seems to be beneficial, from the fuel perspective, as $\mathrm{N}$ contained in fuels tends to be a significant contributor to $\mathrm{NO}_{\mathrm{x}}$ emissions during combustion.

Overall, it can be stated that the results of the proximate and ultimate analysis presented in other studies, published so far on HTC of BSG, support observations presented in this study $[8,9,52]$. Moreover, results indicate that HTC can be an important step in obtaining stable quality of solid fuels, by making them more uniform, despite the variability of the feedstock.

Overall, the indirect method for determination of the mass yield, developed by Weber et al. [49], could give satisfactory results for most of the cases (Figure 7). Only in the case of HTC of spent grain from wheat-based beer, performed at $200{ }^{\circ} \mathrm{C}$ for $120 \mathrm{~min}$, the difference between the mass yield, determined by the direct and indirect method, was significant. On the other hand, the use of ash tracer method leads to significant overestimations of the mass yields, in all of the cases (Figure 7). For the results obtained by Weber method, it seems plausible to suspect that the difference was caused by the fact that inorganic content was affected to the greatest extent by the HTC process, performed at relatively long residence time. Both ash tracer method and Weber method, are based on the assumption that all of the ash, originally present in valorized biomass, remains in the solid product $[49,63]$. However, the Weber method compares the content of ash and fixed carbon combined, thus making the influence of any loss of inorganic part from solid fraction smaller [49]. If $Y_{m}$, determined by ash tracer method (5), is used with respective ash contents of feedstock and product to calculate the $Y_{a}(7)$, then the value of 1.0 is obtained in all of the cases (Figure 8), according to the assumption made for inorganics. However, ash yields obtained, using mass yields determined by the direct method, are smaller than 1.0 in each of the cases. This indicates that a part of inorganic fraction of the original spent grain is lost. This is well in line with generally accepted consensus for hydrothermal carbonization and has been confirmed by a multitude of results from different studies, performed with different types of biomass [27,31,78,79]. Most certainly it is the case of HTC of BSG, even though a part of inorganic substance susceptible to precipitation into liquids is washed out from the malt, during the brewing process, which can be confirmed by a high content of macronutrients in various beers [80]. Poerschmann et al. [52] performed ash analysis of BSG from Reudnitzer Brewery (Leipzig, Germany) and hydrochars produced at $200{ }^{\circ} \mathrm{C}$ and $240{ }^{\circ} \mathrm{C}$. Recovery of ash was ranging between $70 \%$ and $75 \%$ of the original mass of inorganics [52], and in case of $\mathrm{K}$, only $12 \%$ to $14 \%$ remained in the solid product [52]. Poerschmann et al. [52] reported mass yields for HTC of BSG, ranging between 0.511 and 0.475 , at temperatures between $200{ }^{\circ} \mathrm{C}$ and $240{ }^{\circ} \mathrm{C}$, with the residence time of $14 \mathrm{~h}$.

Arauzo et al. [9] reported mass yields for HTC of BSG from Hoepfner Brewery (Karlsruhe, Germany), ranging between 0.680 and 0.506 , at temperatures between $180^{\circ} \mathrm{C}$ and $220^{\circ} \mathrm{C}$, with residence time between 2 and $4 \mathrm{~h}$. The same study reported energy yields ranging between 0.835 and 0.660 [9]. This is reasonably close to the values obtained in this study for residence times of 1 and $2 \mathrm{~h}$ (Figure 9). The differences could be attributed to the source of the origin of BSG and the fact that this study used results of the ultimate analysis to estimate respective HHV values. 


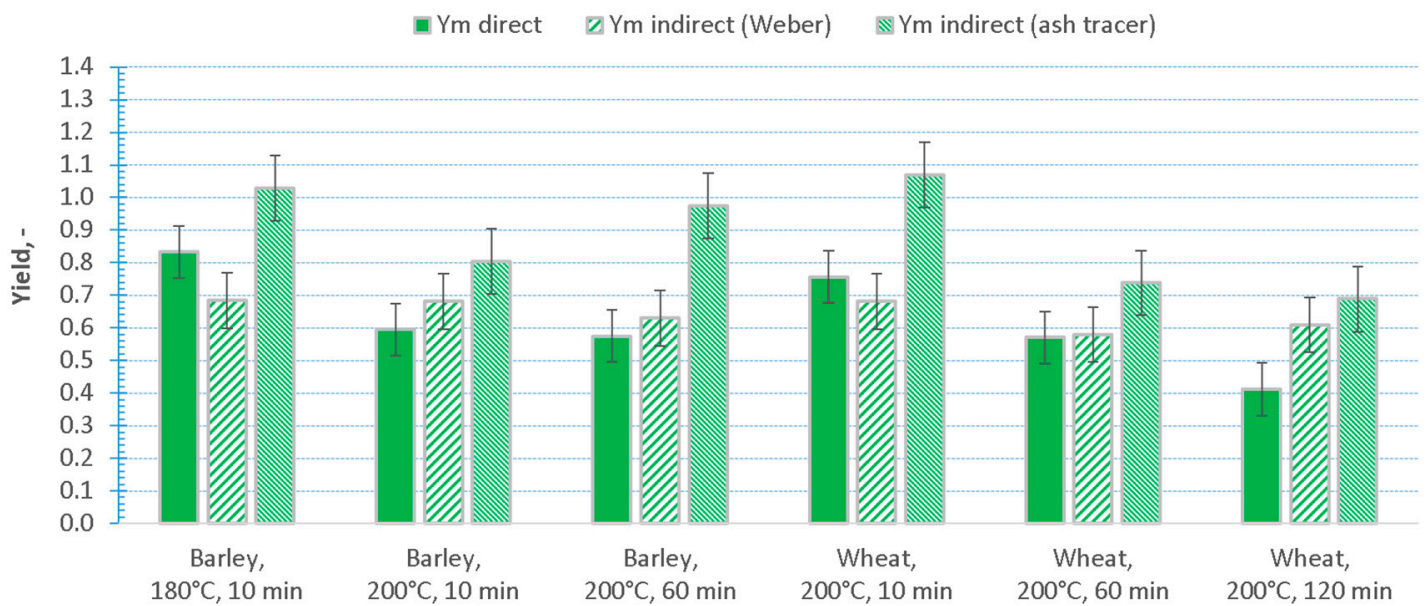

Figure 7. Comparison of mass yield, determined for hydrothermal carbonization experiments, by direct and indirect method.

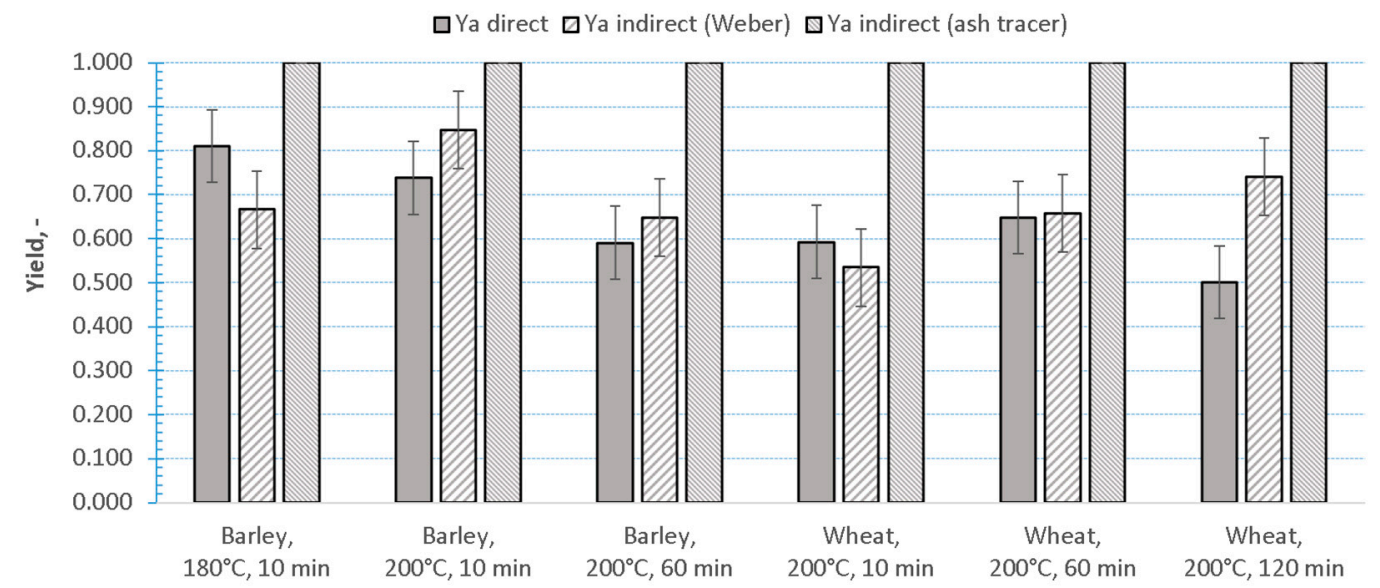

Figure 8. Comparison of ash yield, determined for hydrothermal carbonization experiments, by direct and indirect method.

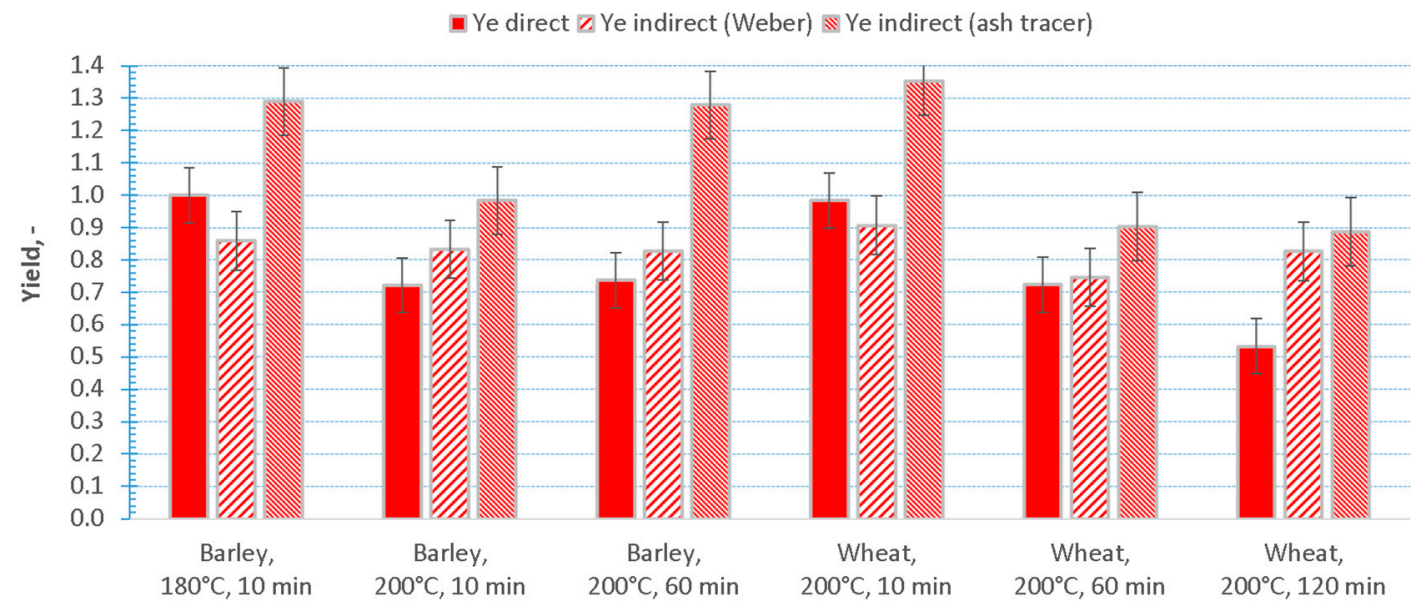

Figure 9. Comparison of energy yield, determined for hydrothermal carbonization experiments, by direct and indirect method.

More stark differences, between feedstocks and corresponding hydrochars were revealed by TGA (Figure 10) and DTG (Figure 11) analysis for pyrolysis of the samples of BSG and corresponding 
hydrochars. Significant differences could be observed between DTG graphs of raw BSG samples and their hydrothermally carbonized counterparts (Figure 11). For both of the cases, raw spent grain has two distinctly different DTG peaks, one at approximately $280^{\circ} \mathrm{C}$ and another close to $340^{\circ} \mathrm{C}$ (Figure 11). Spent grain from wheat beer also has a small peak at approx. $225^{\circ} \mathrm{C}$, whereas for raw barley BSG this peak is minuscule and can be hardly distinguished from the adjacent shoulder (Figure 11).
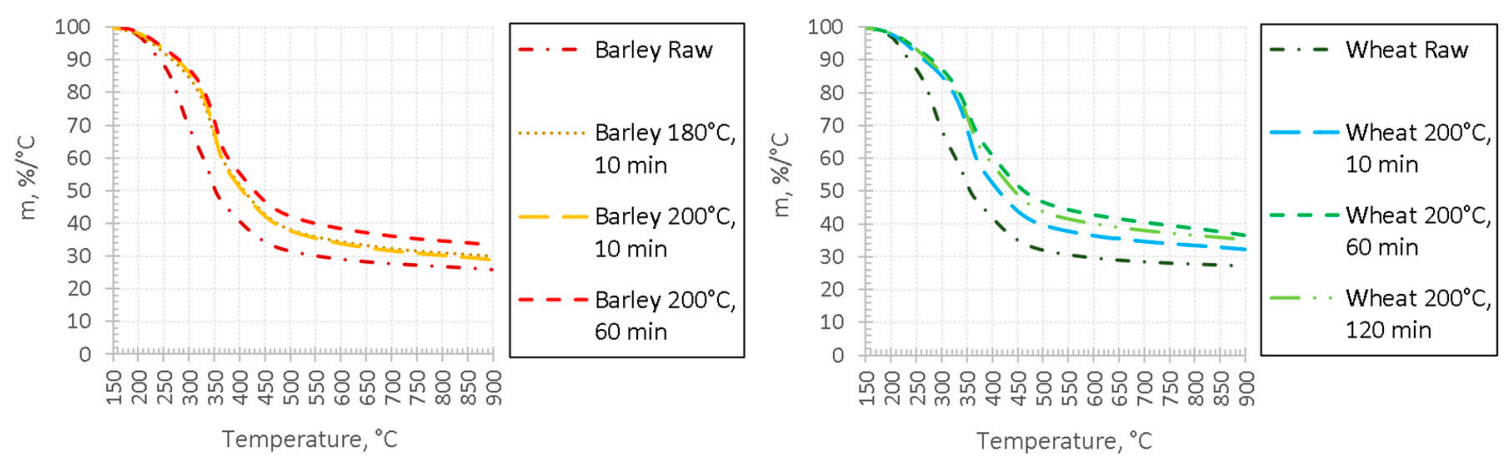

Figure 10. Results of TGA analysis of spent grains from Barley (left) and Wheat (right) and their respective hydrochars, produced in different HTC conditions (pyrolysis conditions- $\mathrm{N}_{2}$ ).
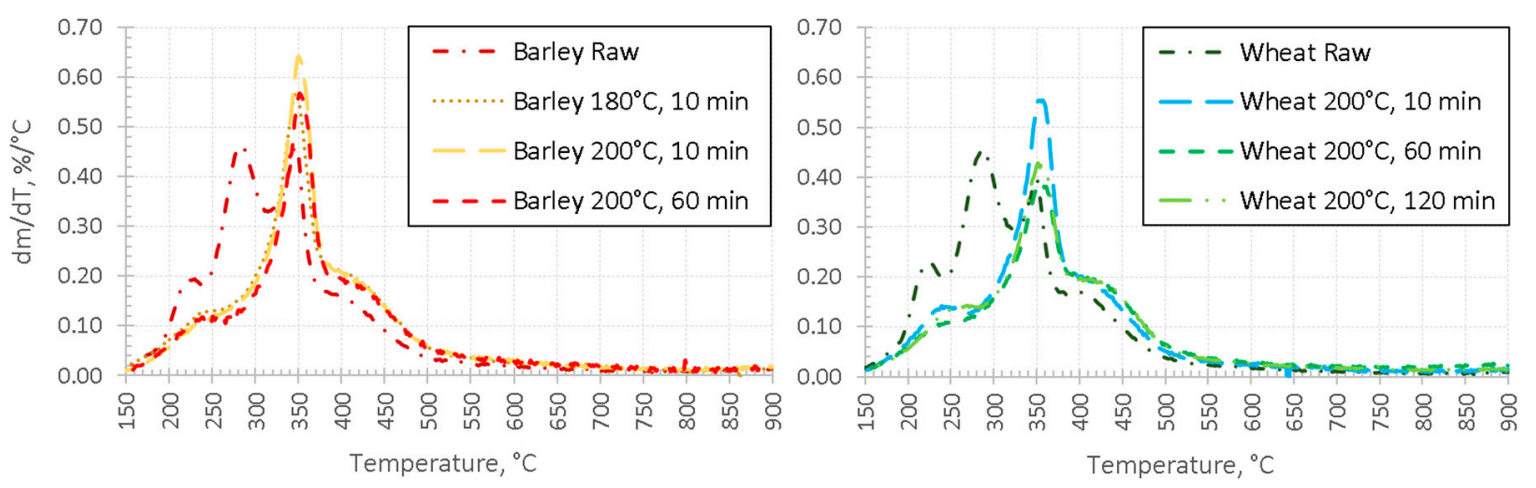

Figure 11. Results of DTG analysis of spent grains from Barley (left) and Wheat (right) and their respective hydrochars, produced in different HTC conditions (pyrolysis conditions- $\mathrm{N}_{2}$ ).

The peaks appearing at $280^{\circ} \mathrm{C}$ and $340{ }^{\circ} \mathrm{C}$ are located fairly similar to peaks that could be found in the work of Beidaghy Dizaji et al. [81] for sugar and wheat flour respectively. Therefore, it seems to be plausible to hypothesize, for both types of raw BSG, that existence of the peaks at approx. $225^{\circ} \mathrm{C}$ and $280^{\circ} \mathrm{C}$ was caused mainly by remaining carbohydrates, that were not processed by the yeast and decomposition of hemicellulose. Arauzo et al. [9] also attributed the large peak, present at $287^{\circ} \mathrm{C}$ for pyrolysis of raw BSG and absent for pyrolysis of corresponding hydrochars, to the decomposition of the hemicellulose [9]. Similar findings were reported by Olszewski et al. [82], and the peak found exclusively for the raw spent grain at $293{ }^{\circ} \mathrm{C}$ was also attributed to hemicellulose [82]. The peak that is common for pyrolysis of raw spent grain and hydrochars, located approximately at $350{ }^{\circ} \mathrm{C}$, was explained by decomposition of cellulose [9,82]. A similar explanation could be given for the existence of the peak present for both types of raw spent grain at $340^{\circ} \mathrm{C}$. However, it seems that it could not be attributed exclusively to cellulose and the influence of the proteins should not be overlooked, as the DTG peaks of different proteins can be found in the literature within similar temperature range [83]. This could be supported by the fact that a significant amount of nitrogen still remains in hydrochars (Figure 5), which might suggest that proteins are not fully decomposed during HTC.

In general, it seems plausible to state that HTC could be a beneficial pre-treatment as far as the use of BSG in a biorefinery is considered. Obtained results (Figure 11) show that the HTC process can make BSG more uniform, as similar DTG profiles could be obtained for BSG samples from the brewing of distinctly different styles of beer. Moreover, HTC allowed maximized release of volatiles closer to 
the temperature region, typical for pyrolysis, aiming at the production of liquids. In contrast to raw BSG samples with a couple of peaks present within a relatively wide range of temperatures, pyrolysis of hydrochars resulted in a single sharp peak close to $350{ }^{\circ} \mathrm{C}$. It seems reasonable to expect that, in such cases, devolatilization would lead to more uniform products which in turn could lead to more uniform composition of pyrolysis oil, after quenching. More research is needed to confirm this hypothesis.

Particle size can have a significant influence on the pyrolysis process [70]. Kinetic data is only relevant for small enough particles, where heat transfer becomes irrelevant [84]. Therefore, additional positive effects of hydrothermal carbonization, as a pre-processing technique for biorefineries, can be clearly seen in Figures 12 and 13. In the case of both feedstocks, HTC resulted in significant improvement of the grindability of hydrochars, in comparison to the raw, dried spent grain. Not much can be found in the literature, regarding the influence of HTC on grindability. Nonetheless, the results presented in this study are in good qualitative agreement with existing literature sources. Wnukowski et al. [39] presented particle size distribution of raw and wet torrefied miscanthus, after comminution in a knife mill. Clear similarity with Figure 12 in this study could be seen as grinding of hydrochars significantly increased the share of fines in the comminuted sample. Moreover, also in the case of miscanthus the differences between respective particle size distributions of samples, carbonized in different HTC conditions, were not as significant as the difference between hydrochars and raw miscanthus [39]. However, the extent of this improvement was much greater, in comparison to this study, as only slightly more than $20 \%$ of total sample mass consisted of particles smaller than $500 \mu \mathrm{m}$, for a cumulative share of particles of raw miscanthus after comminution [39]. A similar trend was reported for miscanthus by Kambo and Dutta [78], with some differences in particle size distribution that could be attributed to the use of different mill (ball mill) [78]. Sharma et al. [85] also reported similar behaviour, for HTC of yard waste, with subsequent milling in a ball mill. Yard waste, collected in autumn, consisted of $65 \%$ (wet biomass) of tree leaves, $33 \%$ of grasses and garden trimmings as well as $2 \%$ fallen sticks and flowers [85]. Overall, it is not surprising that dried spent grain is more grindable in comparison to herbaceous biomass or mixture of herbaceous and woody biomass. This could be undoubtedly attributed to the fibrous nature of lignocellulosic and herbaceous biomass, which is not the case for malt.

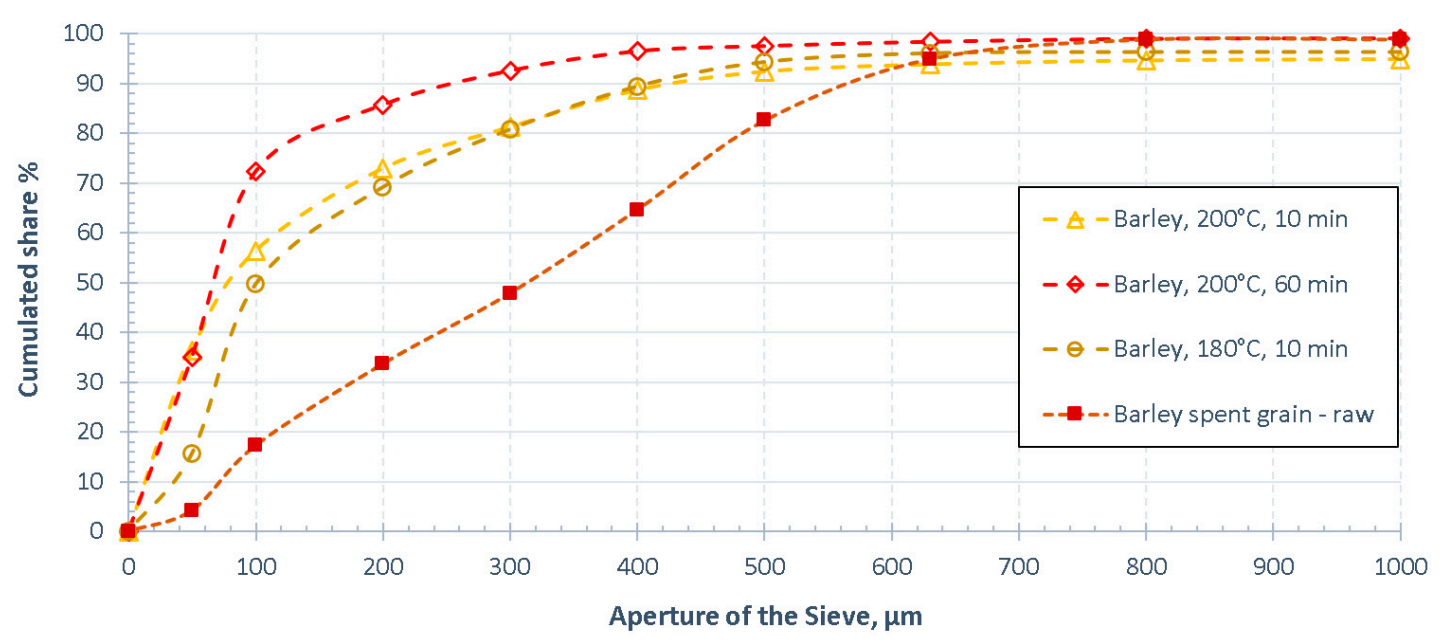

Figure 12. Particle size distribution after grinding spent grain from barley-based beer and respective hydrochars in Retsch SM100 knife mill. 


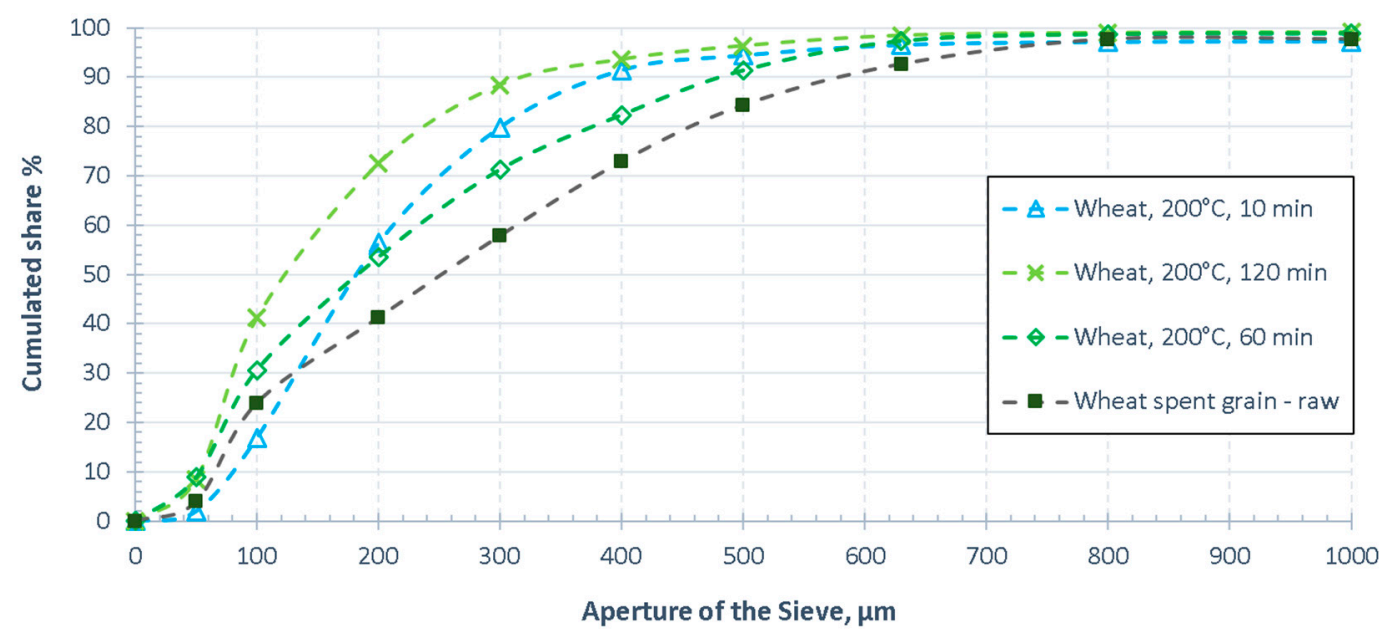

Figure 13. Particle size distribution after grinding spent grain from wheat-based beer and respective hydrochars in Retsch SM100 knife mill.

Figures 12 and 13 show particle size distribution of dried spent grains and corresponding hydrochars. It can be clearly seen that HTC process had positive influence on the grindability for both feedstocks (Figures 12 and 13). However, the extent of the improvement in the grindability, due to use of the HTC process, was different for spent grain from barley and wheat beers (Figures 12 and 13). This could be attributed to the addition of small, slashed branches of juniper, which is fibrous, lignocellulosic biomass. Moreover, malt is a subject of comminution before brewing, and during the process, malt is further broken down physically and thermally, during mashing, lautering and boiling (see Figure 1). Furthermore, the growth of the yeast during fermentation can be considered as a contribution of a part of the mass of the spent grain, at the end of the brewing process [86], which by nature is not hard and durable, thus easy to grind. It could be sensible to recommend further research on the influence of this friable nature on the pelletizing behaviour, as some studies have already reported relatively easy pelletizing of hydrochars [29,87]. According to some of the published studies, it is possible to decrease the energy requirement for pelletizing decreased by half and three quarters, in comparison to typical wood pellets torrefied wood pellets, respectively [88].

Detailed mass, energy and carbon balances are presented, for selected HTC conditions for both types of spent grain, in Figure 14. It is difficult to select optimum HTC conditions if pre-processed feedstock is intended to be used in a biorefinery, if quality of the pyrolysis oil cannot be assessed. Nonetheless, existing literature indicates that oxygen has detrimental influence on quality of pyrolysis oil, as it increases the content of unstable oxygenated compounds among the liquid products of pyrolysis $[73,74,89]$. Therefore, the lowest possible O/C content (Figure 4) was ultimately chosen as the criterium of this selection. Based on this criterium, HTC at $200{ }^{\circ} \mathrm{C}$, with residence time of $60 \mathrm{~min}$, has been selected as optimum pretreatment conditions for both types of feedstock.

A part of carbon is lost to the liquids in both of the cases presented in Figure 14. Similarly, approximately one third of the original chemical energy of the feedstock is lost to by-products. However, this energy can be recovered by adding this liquid into anaerobic digestion reactors, as suggested by many studies of HTC of different types of biomass [43,69,90-95].

It seems prudent to suggest more research in two areas. Firstly, extensive research on composition of pyrolysis oil from HTC treated BSG, including influence of the particle size, would be beneficial in terms of obtaining definite answer on optimum HTC parameters for biorefinery purposes. Moreover, anaerobic digestion of liquid by-products of HTC of brewer's spent grain should also become a subject of detailed experimental investigation. 

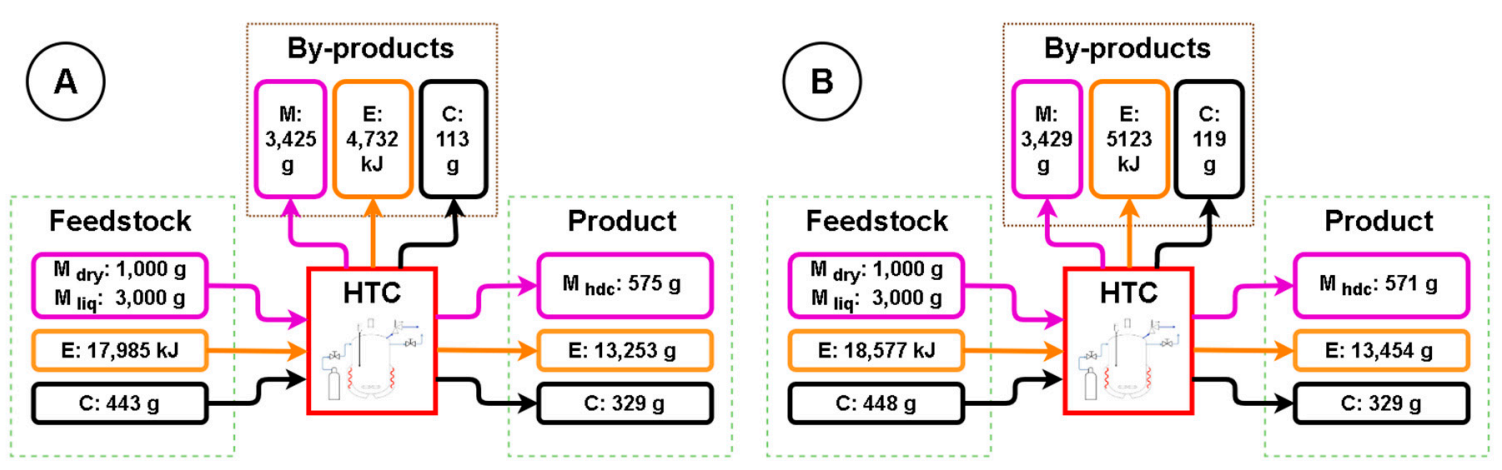

Figure 14. Mass, energy, and carbon balance for selected HTC parameters: A-Barley-based BSG after HTC at $200{ }^{\circ} \mathrm{C}, 60 \mathrm{~min}$; B-Wheat-based BSG after HTC at $200{ }^{\circ} \mathrm{C}, 60 \mathrm{~min}$. (M-mass; $\mathrm{M}_{\text {dry }}-$ mass of dry solids; $\mathrm{M}_{\mathrm{liq}}$-mass of water; $\mathrm{M}_{\mathrm{hdc}}-$ mass of dry hydrochar; E-energy; $\mathrm{C}$-carbon).

\section{Conclusions}

Overall, the differences in the feedstock and parameters of the brewing process resulted in two different beers. Thus, it was reasonable to expect two distinctly different by-products (BSG) as a result. However, the differences in terms of the fuel properties of both types of BSG were much less stark in comparison to the initial assumptions.

In general, the use of HTC as a pretreatment of BSG for subsequent use as a biorefinery feedstock can be considered beneficial. HTC was helpful in uniformization and improvement of the fuel properties. Significant decrease in the oxygen content and $\mathrm{O} / \mathrm{C}$ ratio, which should be considered beneficial, as available literature considers high oxygen content detrimental for the quality and stability of the pyrolysis oil, attributed to the oxygenated compounds. The HTC process made BSG more uniform, as similar DTG profiles could be obtained for BSG samples from the brewing of distinctly different styles of beer. Moreover, HTC allowed maximized release of volatiles closer to the temperature region, typical for pyrolysis aiming at the production of liquids. In contrast to raw BSG samples with a couple of peaks present within a relatively wide range of temperatures, pyrolysis of hydrochars resulted in a single sharp peak close to $350^{\circ} \mathrm{C}$.

The extent of the improvement in the grindability, due to use of the HTC process, was different for spent grain from barley and wheat beers. However, in both of the cases, improvement of the grindability could be observed.

From the indirect methods for assessment of the productivity of the HTC process, the Weber method could give satisfactory results for most of the cases. Traditional ash tracer method resulted in significant overestimations of the mass yield, thus making this method not suitable for the future use in commercial-scale installations.

It seems to be reasonable to recommend further research on the influence of HTC on the overall quality and composition of pyrolysis oil from pyrolysis of BSG. Further research on different routes of the utilization of HTC liquid byproducts, such as the use of this liquid for anaerobic digestion, is also recommended. Filling this knowledge gap is a prerequisite for the practical implementation of the HTC process in the future biorefineries, conforming to the circular economy standards.

Author Contributions: Conceptualization: M.J. and L.N.; methodology: M.J., L.N., and M.W.; validation: M.W., M.J., M.B., M.L., and M.T.-S.; formal analysis: M.J., M.W., M.B., and M.T.-S.; investigation: M.J., M.W., M.T.-S., K.K. and V.K.V.; resources: A.T., H.P.-K., and A.A.; data curation: V.K.V., M.L., M.B., and M.T.-S.; writing-original draft preparation: M.J. and L.N.; writing—review and editing: M.J. and L.N.; visualization: L.N. and M.J.; supervision: A.T., H.P.-K., A.A., and P.S. All authors have read and agreed to the published version of the manuscript.

Funding: Financial support of this research from the National Science Centre, Poland-project no. 2019/33/N/ST8/02641, is gratefully acknowledged.

Conflicts of Interest: The authors declare no conflict of interest. 


\section{References}

1. Bentzen, J.; Smith, V. Structural Changes in the Consumption of Beer, Wine and Spirits in OECD Countries from 1961 to 2014. Beverages 2018, 4, 8. [CrossRef]

2. Lynch, K.M.; Steffen, E.J.; Arendt, E.K. Brewers' spent grain: A review with an emphasis on food and health. J. Inst. Brew. 2016, 122, 553-568. [CrossRef]

3. Kerby, C.; Vriesekoop, F. An Overview of the Utilisation of Brewery By-Products as Generated by British Craft Breweries. Beverages 2017, 3, 24. [CrossRef]

4. Özvural, E.B.; Vural, H.; Gökbulut, İ.; Özboy-Özbaş, Ö. Utilization of brewer's spent grain in the production of Frankfurters. Int. J. Food Sci. Technol. 2009, 44, 1093-1099. [CrossRef]

5. Stojceska, V.; Ainsworth, P. The effect of different enzymes on the quality of high-fibre enriched brewer's spent grain breads. Food Chem. 2008, 110, 865-872. [CrossRef] [PubMed]

6. Combest, S.; Warren, C. Perceptions of college students in consuming whole grain foods made with Brewers ' Spent Grain. Food Sci. Nutr. 2019, 7, 225-237. [CrossRef] [PubMed]

7. Sperandio, G.; Amoriello, T.; Carbone, K.; Fedrizzi, M.; Monteleone, A.; Tarangioli, S.; Pagano, M. Increasing the value of spent grain from craft microbreweries for energy purposes. Chem. Eng. Trans. 2017, 58, 487-492. [CrossRef]

8. Jackowski, M.; Semba, D.; Trusek, A.; Wnukowski, M.; Niedzwiecki, L.; Baranowski, M.; Krochmalny, K.; Pawlak-Kruczek, H. Hydrothermal Carbonization of Brewery's Spent Grains for the Production of Solid Biofuels. Beverages 2019, 5, 12. [CrossRef]

9. Arauzo, P.; Olszewski, M.; Kruse, A. Hydrothermal Carbonization Brewer's Spent Grains with the Focus on Improving the Degradation of the Feedstock. Energies 2018, 11, 3226. [CrossRef]

10. Alonso-Riaño, P.; Sanz Diez, M.T.; Blanco, B.; Beltrán, S.; Trigueros, E.; Benito-Román, O. Water Ultrasound-Assisted Extraction of Polyphenol Compounds from Brewer's Spent Grain: Kinetic Study, Extract Characterization, and Concentration. Antioxidants 2020, 9, 265. [CrossRef]

11. Birsan, R.I.; Wilde, P.; Waldron, K.W.; Rai, D.K. Recovery of polyphenols from brewer's spent grains. Antioxidants 2019, 8, 380. [CrossRef] [PubMed]

12. Tan, Y.X.; Mok, W.K.; Lee, J.; Kim, J.; Chen, W.N. Solid state fermentation of Brewers' spent grains for improved nutritional profile using Bacillus subtilis WX-17. Fermentation 2019, 5, 52. [CrossRef]

13. Zuorro, A.; Iannone, A.; Lavecchia, R. Water-organic solvent extraction of phenolic antioxidants from brewers' spent grain. Processes 2019, 7, 126. [CrossRef]

14. Lordan, R.; O'Keeffe, E.; Tsoupras, A.; Zabetakis, I. Total, neutral, and polar lipids of brewing ingredients, by-products and beer: Evaluation of antithrombotic activities. Foods 2019, 8, 171. [CrossRef] [PubMed]

15. Du, L.; Arauzo, P.J.; Meza Zavala, M.F.; Cao, Z.; Olszewski, M.P.; Kruse, A. Towards the properties of different biomass-derived proteins via various extraction methods. Molecules 2020, 25, 488. [CrossRef]

16. Mancini, S.; Fratini, F.; Turchi, B.; Mattioli, S.; Dal Bosco, A.; Tuccinardi, T.; Nozic, S.; Paci, G. Former foodstuff products in Tenebrio molitor rearing: Effects on growth, chemical composition, microbiological load, and antioxidant status. Animals 2019, 9, 484. [CrossRef]

17. Ferreira, A.M.; Martins, J.; Carvalho, L.H.; Magalhães, F.D. Biosourced disposable trays made of brewer's spent grain and potato starch. Polymers 2019, 11, 923. [CrossRef]

18. Zedler, Ł.; Colom, X.; Cañavate, J.; Saeb, M.R.; Haponiuk, J.T.; Formela, K. Investigating the Impact of Curing System on Structure-Property Relationship of Natural Rubber Modified with Brewery By-Product and Ground Tire Rubber. Polymers 2020, 12, 545. [CrossRef] [PubMed]

19. Silbir, S.; Goksungur, Y. Natural red pigment production by monascus purpureus in submerged fermentation systems using a food industry waste: Brewer's spent grain. Foods 2019, 8, 161. [CrossRef]

20. Amoriello, T.; Fiorentino, S.; Vecchiarelli, V.; Pagano, M. Evaluation of spent grain biochar impact on hop (Humulus lupulus L.) growth by multivariate image analysis. Appl. Sci. 2020, 10, 533. [CrossRef]

21. Cancelliere, R.; Carbone, K.; Pagano, M.; Cacciotti, I.; Micheli, L. Biochar from brewers' spent grain: A green and low-cost smart material to modify screen-printed electrodes. Biosensors 2019, 9, 139. [CrossRef] [PubMed]

22. Enweremadu, C.; Waheed, M.A.; Adekunle, A.A.; Adeala, A. The Energy Potential of Brewer's Spent Grain for Breweries in Nigeria. Eng. Appl. Sci. 2008, 3, 175-177.

23. Liguori, R.; Soccol, C.R.; de Souza Vandenberghe, L.P.; Woiciechowski, A.L.; Faraco, V. Second generation ethanol production from brewers' spent grain. Energies 2015, 8, 2575-2586. [CrossRef] 
24. Reza, M.T.; Andert, J.; Wirth, B.; Busch, D.; Pielert, J.; Lynam, J.G.; Mumme, J. Hydrothermal Carbonization of Biomass for Energy and Crop Production. Appl. Bioenergy 2014, 1, 11-29. [CrossRef]

25. Funke, A.; Ziegler, F. Hydrothermal carbonisation of biomass: A summary and discussion of chemical mechanisms for process engineering. Biofuels Bioprod. Biorefining 2010, 4, 160-177. [CrossRef]

26. Kruse, A.; Funke, A.; Titirici, M.M. Hydrothermal conversion of biomass to fuels and energetic materials. Curr. Opin. Chem. Biol. 2013, 17, 515-521. [CrossRef] [PubMed]

27. Moscicki, K.J.; Niedzwiecki, L.; Owczarek, P.; Wnukowski, M. Commoditization of wet and high ash biomass: Wet torrefaction-A review. J. Power Technol. 2017, 97, 354-369.

28. Codignole Luz, F.; Volpe, M.; Fiori, L.; Manni, A.; Cordiner, S.; Mulone, V.; Rocco, V. Spent coffee enhanced biomethane potential via an integrated hydrothermal carbonization-anaerobic digestion process. Bioresour. Technol. 2018, 256, 102-109. [CrossRef]

29. Volpe, M.; Wüst, D.; Merzari, F.; Lucian, M.; Andreottola, G.; Kruse, A.; Fiori, L. One stage olive mill waste streams valorisation via hydrothermal carbonisation. Waste Manag. 2018, 80, 224-234. [CrossRef]

30. Gao, L.; Volpe, M.; Lucian, M.; Fiori, L.; Goldfarb, J.L. Does Hydrothermal Carbonization as a Biomass Pretreatment Reduce Fuel Segregation of Coal-Biomass Blends During Oxidation? Energy Convers. Manag. 2018, 181, 93-104. [CrossRef]

31. Reza, M.T.; Lynam, J.G.; Uddin, M.H.; Coronella, C.J. Hydrothermal carbonization: Fate of inorganics. Biomass Bioenergy 2013, 49, 86-94. [CrossRef]

32. Reza, M.T.; Yan, W.; Uddin, M.H.; Lynam, J.G.; Hoekman, S.K.; Coronella, C.J.; Vásquez, V.R. Reaction kinetics of hydrothermal carbonization of loblolly pine. Bioresour. Technol. 2013, 139, 161-169. [CrossRef]

33. Tungal, R.; Shende, R.V. Hydrothermal liquefaction of pinewood (Pinus ponderosa) for H2, biocrude and bio-oil generation. Appl. Energy 2014, 134, 401-412. [CrossRef]

34. Nan, W.; Shende, A.R.; Shannon, J.; Shende, R.V. Insight into Catalytic Hydrothermal Liquefaction of Cardboard for Biofuels Production. Energy Fuels 2016, 30, 4933-4944. [CrossRef]

35. Shende, R.; Tungal, R. Subcritical Aqueous Phase Reforming of Wastepaper for Biocrude and H2 Generation. Energy Fuels 2013, 27, 3194-3203. [CrossRef]

36. Funke, A.; Ziegler, F. Heat of reaction measurements for hydrothermal carbonization of biomass. Bioresour. Technol. 2011, 102, 7595-7598. [CrossRef]

37. Acharjee, T.C.; Coronella, C.J.; Vasquez, V.R. Effect of thermal pretreatment on equilibrium moisture content of lignocellulosic biomass. Bioresour. Technol. 2011, 102, 4849-4854. [CrossRef]

38. Gao, N.; Li, Z.; Quan, C.; Miskolczi, N.; Egedy, A. A new method combining hydrothermal carbonization and mechanical compression in-situ for sewage sludge dewatering: Bench-scale verification. J. Anal. Appl. Pyrolysis 2019, 139, 187-195. [CrossRef]

39. Wnukowski, M.; Owczarek, P.; Niedźwiecki, Ł. Wet Torrefaction of Miscanthus-Characterization of Hydrochars in View of Handling, Storage and Combustion Properties. J. Ecol. Eng. 2015, 16, 161-167. [CrossRef]

40. Magdziarz, A.; Wilk, M.; Wądrzyk, M. Pyrolysis of hydrochar derived from biomass-Experimental investigation. Fuel 2020, 267, 117246. [CrossRef]

41. Wilk, M.; Magdziarz, A. Hydrothermal carbonization, torrefaction and slow pyrolysis of Miscanthus giganteus. Energy 2017, 140, 1292-1304. [CrossRef]

42. Wilk, M.; Magdziarz, A.; Jayaraman, K.; Szymańska-Chargot, M.; Gökalp, I. Hydrothermal carbonization characteristics of sewage sludge and lignocellulosic biomass. A comparative study. Biomass Bioenergy 2019, 120, 166-175. [CrossRef]

43. Aragón-Briceño, C.; Ross, A.B.; Camargo-Valero, M.A. Evaluation and comparison of product yields and bio-methane potential in sewage digestate following hydrothermal treatment. Appl. Energy 2017, 208, 1357-1369. [CrossRef]

44. Paul, S.; Dutta, A.; Defersha, F. Mechanical and alkaline hydrothermal treated corn residue conversion in to bioenergy and biofertilizer: A resource recovery concept. Energies 2018, 11, 516. [CrossRef]

45. Steinbach, D.; Kruse, A.; Sauer, J.; Vetter, P. Sucrose is a promising feedstock for the synthesis of the platform chemical hydroxymethylfurfural. Energies 2018, 11, 645. [CrossRef] 
46. Dieguez-Alonso, A.; Funke, A.; Anca-Couce, A.; Rombolà, A.G.; Ojeda, G.; Bachmann, J.; Behrendt, F. Towards biochar and hydrochar engineering-influence of process conditions on surface physical and chemical properties, thermal stability, nutrient availability, toxicity and wettability. Energies 2018, 11, 496. [CrossRef]

47. Kruse, A.; Zevaco, T.A. Properties of hydrochar as function of feedstock, reaction conditions and post-treatment. Energies 2018, 11, 674. [CrossRef]

48. Wang, S.; Persson, H.; Yang, W.; Jönsson, P.G. Pyrolysis study of hydrothermal carbonization-treated digested sewage sludge using a Py-GC/MS and a bench-scale pyrolyzer. Fuel 2019, 262, 116335. [CrossRef]

49. Weber, K.; Heuer, S.; Quicker, P.; Li, T.; Løvås, T.; Scherer, V. An Alternative Approach for the Estimation of Biochar Yields. Energy Fuels 2018, 32, 9506-9512. [CrossRef]

50. Arranz, J.I.; Miranda, M.T.; Sepúlveda, F.J.; Montero, I.; Rojas, C.V. Analysis of Drying of Brewers' Spent Grain. Proceedings 2018, 2, 1467. [CrossRef]

51. Dudek, M.; Świechowski, K.; Manczarski, P.; Koziel, J.A.; Białowiec, A. The effect of biochar addition on the biogas production kinetics from the anaerobic digestion of brewers' spent grain. Energies 2019, 12, 1518. [CrossRef]

52. Poerschmann, J.; Weiner, B.; Wedwitschka, H.; Baskyr, I.; Koehler, R.; Kopinke, F.D. Characterization of biocoals and dissolved organic matter phases obtained upon hydrothermal carbonization of brewer's spent grain. Bioresour. Technol. 2014, 164, 162-169. [CrossRef] [PubMed]

53. Olszewski, M.P.; Arauzo, P.J.; Wadrzyk, M.; Kruse, A. Py-GC-MS of hydrochars produced from brewer's spent grains. J. Anal. Appl. Pyrolysis 2019, 140, 255-263. [CrossRef]

54. Olszewski, M.P.; Nicolae, S.A.; Arauzo, P.J.; Titirici, M.M.; Kruse, A. Wet and dry? Influence of hydrothermal carbonization on the pyrolysis of spent grains. J. Clean. Prod. 2020, 260, 121101. [CrossRef]

55. European Comitte for Standardisation (CEN). EN ISO 18122:2015 Solid Biofuels—Determination of Ash Content; BSI Standards Limited: London, UK, 2015; ISBN 9780580814273.

56. European Comitte for Standardisation (CEN). EN 15148:2009 Solid Biofuels—Determination of the Content of Volatile Matter; BSI Standards Limited: London, UK, 2009; ISBN 9780580666940.

57. European Comitte for Standardisation (CEN). EN ISO 16948:2015 Determination of Total Content of Carbon, Hydrogen and Nitrogen-Instrumental Methods; BSI Standards Limited: London, UK, 2015; ISBN 9780580 814631.

58. Friedl, A.; Padouvas, E.; Rotter, H.; Varmuza, K. Prediction of heating values of biomass fuel from elemental composition. Anal. Chim. Acta 2005, 544, 191-198. [CrossRef]

59. Lachos-Perez, D.; Brown, A.B.; Mudhoo, A.; Martinez, J.; Timko, M.T.; Rostagno, M.A.; Forster-Carneiro, T. Applications of subcritical and supercritical water conditions for extraction, hydrolysis, gasification, and carbonization of biomass: A critical review. Biofuel Res. J. 2017, 4, 611-626. [CrossRef]

60. Pawlak-Kruczek, H.; Krochmalny, K.; Mościcki, K.; Zgóra, J.; Czerep, M.; Ostrycharczyk, M.; Niedźwiecki, Ł. Torrefaction of Various Types of Biomass in Laboratory Scale, Batch-Wise Isothermal Rotary Reactor and Pilot Scale, Continuous Multi-Stage Tape Reactor. Eng. Prot. Environ. 2017, 20, 457-472. [CrossRef]

61. Moscicki, K.J.; Niedzwiecki, L.; Owczarek, P.; Wnukowski, M. Commoditization of biomass: Dry torrefaction and pelletization-a review. J. Power Technol. 2014, 94, 233-249.

62. Pawlak-Kruczek, H.; Krochmalny, K.K.; Wnukowski, M.; Niedzwiecki, L. Slow pyrolysis of the sewage sludge with additives: Calcium oxide and lignite. J. Energy Resour. Technol. 2018, 140, 062206. [CrossRef]

63. Liaw, S.B.; Wu, H. A New Method for Direct Determination of Char Yield during Solid Fuel Pyrolysis in Drop-Tube Furnace at High Temperature and Its Comparison with Ash Tracer Method. Energy Fuels 2019, 33 , 1509-1517. [CrossRef]

64. Poudel, J.; Karki, S.; Gu, J.H.; Lim, Y.; Oh, S.C. Effect of Co-Torrefaction on the Properties of Sewage Sludge and Waste Wood to Enhance Solid Fuel Qualities. J. Residuals Sci. Technol. 2017, 14, 23-36. [CrossRef]

65. Pulka, J.; Wiśniewski, D.; Gołaszewski, J.; Białowiec, A. Is the biochar produced from sewage sludge a good quality solid fuel? Arch. Environ. Prot. 2016, 42, 125-134. [CrossRef]

66. Thompson Witrick, K.; Duncan, S.; Hurley, K.; O'Keefe, S. Acid and Volatiles of Commercially-Available Lambic Beers. Beverages 2017, 3, 51. [CrossRef]

67. Bach, Q.V.; Tran, K.Q.; Skreiberg, O.; Khalil, R.A.; Phan, A.N. Effects of wet torrefaction on reactivity and kinetics of wood under air combustion conditions. Fuel 2014, 137, 375-383. [CrossRef] 
68. Puccini, M.; Ceccarini, L.; Antichi, D.; Seggiani, M.; Tavarini, S.; Latorre, M.H.; Vitolo, S. Hydrothermal carbonization of municipal woody and herbaceous prunings: Hydrochar valorisation as soil amendment and growth medium for horticulture. Sustainability 2018, 10, 846. [CrossRef]

69. Parmar, K.R.; Ross, A.B. Integration of hydrothermal carbonisation with anaerobic digestion; Opportunities for valorisation of digestate. Energies 2019, 12, 1586. [CrossRef]

70. Mlonka-Mędrala, A.; Magdziarz, A.; Dziok, T.; Sieradzka, M.; Nowak, W. Laboratory studies on the influence of biomass particle size on pyrolysis and combustion using TG GC/MS. Fuel 2019, 252, 635-645. [CrossRef]

71. Broch, A.; Jena, U.; Hoekman, S.K.; Langford, J. Analysis of solid and aqueous phase products from hydrothermal carbonization of whole and lipid-extracted algae. Energies 2014, 7, 62-79. [CrossRef]

72. Zhang, B.; Heidari, M.; Regmi, B.; Salaudeen, S.; Arku, P.; Thimmannagari, M.; Dutta, A. Hydrothermal carbonization of fruit wastes: A promising technique for generating hydrochar. Energies 2018, 11, 22. [CrossRef]

73. Bridgwater, A.V. Review of fast pyrolysis of biomass and product upgrading. Biomass Bioenergy 2012, 38, 68-94. [CrossRef]

74. Louwes, A.C.; Basile, L.; Yukananto, R.; Bhagwandas, J.C.; Bramer, E.A.; Brem, G. Torrefied biomass as feed for fast pyrolysis: An experimental study and chain analysis. Biomass Bioenergy 2017, 105, 116-126. [CrossRef]

75. Naqvi, S.R.; Prabhakara, H.M.; Bramer, E.A.; Dierkes, W.; Akkerman, R.; Brem, G. A critical review on recycling of end-of-life carbon fibre/glass fibre reinforced composites waste using pyrolysis towards a circular economy. Resour. Conserv. Recycl. 2018, 136, 118-129. [CrossRef]

76. Guo, M.; Jin, Y.; Du, J.; Zhang, K.; Zhao, D. Effects of wheat protein compositions on malt quality. Qual. Assur. Saf. Crop. Foods 2014, 6, 73-80. [CrossRef]

77. Magliano, P.N.; Prystupa, P.; Gutiérrez-Boem, F.H. Protein content of grains of different size fractions in malting barley. J. Inst. Brew. 2014, 120, 347-352. [CrossRef]

78. Kambo, H.S.; Dutta, A. Comparative evaluation of torrefaction and hydrothermal carbonization of lignocellulosic biomass for the production of solid biofuel. Energy Convers. Manag. 2015, 105, 746-755. [CrossRef]

79. Smith, A.M.; Singh, S.; Ross, A.B. Fate of inorganic material during hydrothermal carbonisation of biomass: Influence of feedstock on combustion behaviour of hydrochar. Fuel 2016, 169, 135-145. [CrossRef]

80. Alcázar, A.; Pablos, F.; Martín, M.J.; González, A.G. Multivariate characterisation of beers according to their mineral content. Talanta 2002, 57, 45-52. [CrossRef]

81. Beidaghy Dizaji, H.; Faraji Dizaji, F.; Bidabadi, M. Determining thermo-kinetic constants in order to classify explosivity of foodstuffs. Combust. Explos. Shock Waves 2014, 50, 454-462. [CrossRef]

82. Olszewski, M.P.; Arauzo, P.J.; Maziarka, P.A.; Ronsse, F.; Kruse, A. Pyrolysis Kinetics of Hydrochars Produced from Brewer's Spent Grains. Catalysts 2019, 9, 625. [CrossRef]

83. Gui, Y.; Li, J.; Zhu, Y.; Guo, L. Roles of four enzyme crosslinks on structural, thermal and gel properties of potato proteins. LWT - Food Sci. Technol. 2020, 123, 109116. [CrossRef]

84. Pyle, D.L.; Zaror, C.A. Heat transfer and kinetics in the low temperature pyrolysis of solids. Chem. Eng. Sci. 1984, 39, 147-158. [CrossRef]

85. Sharma, H.B.; Panigrahi, S.; Dubey, B.K. Hydrothermal carbonization of yard waste for solid bio-fuel production: Study on combustion kinetic, energy properties, grindability and flowability of hydrochar. Waste Manag. 2019, 91, 108-119. [CrossRef]

86. Wang, W.; Jiang, H.; Liu, G.H.; Mei, C.L.; Ji, Y. Qualitative Prediction of Yeast Growth Process Based on Near Infrared Spectroscopy. Chin. J. Anal. Chem. 2017, 45, 1137-1141. [CrossRef]

87. Liu, Z.; Quek, A.; Balasubramanian, R. Preparation and characterization of fuel pellets from woody biomass, agro-residues and their corresponding hydrochars. Appl. Energy 2014, 113, 1315-1322. [CrossRef]

88. Koppejan, J.; Sokhansanj, S.; Melin, S.; Madrali, S. Status Overview of Torrefaction Technologies; International Energy Agency: Paris, France, 2015.

89. Butler, E.; Devlin, G.; Meier, D.; McDonnell, K. A review of recent laboratory research and commercial developments in fast pyrolysis and upgrading. Renew. Sustain. Energy Rev. 2011, 15, 4171-4186. [CrossRef]

90. Weiner, B.; Poerschmann, J.; Wedwitschka, H.; Koehler, R.; Kopinke, F.-D. Influence of Process Water Reuse on the Hydrothermal Carbonization of Paper. ACS Sustain. Chem. Eng. 2014, 2, 2165-2171. [CrossRef] 
91. Erdogan, E.; Atila, B.; Mumme, J.; Reza, M.T.; Toptas, A.; Elibol, M.; Yanik, J. Characterization of products from hydrothermal carbonization of orange pomace including anaerobic digestibility of process liquor. Bioresour. Technol. 2015, 196, 35-42. [CrossRef] [PubMed]

92. Wirth, B.; Mumme, J. Anaerobic Digestion of Waste Water from Hydrothermal Carbonization of Corn Silage. Appl. Bioenergy 2014, 1, 1-10. [CrossRef]

93. Usman, M.; Chen, H.; Chen, K.; Ren, S.; Clark, J.H.; Fan, J.; Luo, G.; Zhang, S. Characterization and utilization of aqueous products from hydrothermal conversion of biomass for bio-oil and hydro-char production: A review. Green Chem. 2019, 21, 1553-1572. [CrossRef]

94. Villamil, J.A.; Mohedano, A.F.; Rodríguez, J.J.; Borja, R.; De la Rubia, M.A. Anaerobic Co-digestion of the Organic Fraction of Municipal Solid Waste and the Liquid Fraction From the Hydrothermal Carbonization of Industrial Sewage Sludge Under Thermophilic Conditions. Front. Sustain. Food Syst. 2018, 2, 1-7. [CrossRef]

95. Svensson, K.; Kjørlaug, O.; Higgins, M.J.; Linjordet, R.; Horn, S.J. Post-anaerobic digestion thermal hydrolysis of sewage sludge and food waste: Effect on methane yields, dewaterability and solids reduction. Water Res. 2018, 132, 158-166. [CrossRef] [PubMed]

C 2020 by the authors. Licensee MDPI, Basel, Switzerland. This article is an open access article distributed under the terms and conditions of the Creative Commons Attribution (CC BY) license (http://creativecommons.org/licenses/by/4.0/). 